INEL/EXT-97-00362

May 1997

\title{
Aquatic Plant Control Research
}

\section{RECEIVED NOV 0 ๖ 1997 \\ OSTI}

P. A. Pryfogle

B. N.Rinehart

E. G. Ghio*

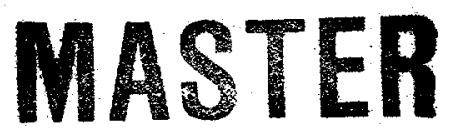

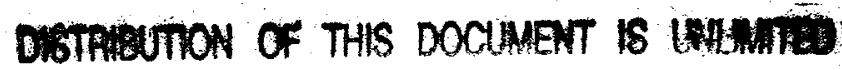




\title{
Aquatic Plant Control Research
}

\author{
P. A. Pryfogle \\ B. N. Rinehart \\ E. G. Ghio*
}

Published May 1997

Idaho National Engineering Laboratory Renewable Energy Products Department

Lockheed Martin Idaho Technologies Company

Idaho Falls, Idaho 83415

*Pacific Gas \& Electric Company

Hydro Generation Engineering

San Francisco, California

Prepared for the

U.S. Department of Energy

Assistant Secretary for Energy Efficiency and Renewable Energy

Under DOE Idaho Operations Office

Contract DE-AC07-94ID13223 


\section{DISCLAIMER}

This report was prepared as an account of work sponsored by an agency of the United States Government. Neither the United States Government nor any agency thereof, nor any of their employees, makes any warranty, express or implied, or assumes any legal liability or responsibility for the accuracy, completeness, or usefulness of any information, apparatus, product, or process disclosed, or represents that its use would not infringe privately owned rights. Reference herein to any specific commercial product, process, or service by trade name, trademark, manufacturer, or otherwise does not necessarily constitute or imply its endorsement, recommendation, or favoring by the United States Government or any agency thereof. The views and opinions of authors expressed herein do not necessarily state or reflect those of the United States Government or any agency thereof. 


\section{DISCLAIMER}

Portions of this document may be illegible electronic image products. Images are produced from the best available original document. 


\begin{abstract}
The Northwest region of the United States contains extensive canal systems that transport water for hydropower generation. Nuisance plants, including algae, that grow in these systems reduce their hydraulic capacity through water displacement and increased surface friction. Most control methods are applied in an ad hoc fashion. The goal of this work is to develop cost-effective, environmentally sound, long-term management strategies to prevent and control nuisance algal growth. This paper reports on a multi-year study, performed in collaboration with the Pacific Gas \& Electric Company, to investigate algal growth in their canal systems, and to evaluate various control methodologies. Three types of controls, including mechanical, biological and chemical treatment, were selected for testing and evaluation. As part of this study, water quality data were collected and algal communities were sampled from numerous stations throughout the distribution system at regular intervals. This study resulted in a more comprehensive understanding of conditions leading to the development of nuisance algal growth, a better informed selection of treatment plans, and improved evaluation of the effectiveness for the control strategies selected for testing.
\end{abstract}




\section{SUMMARY}

The Northwest region of the United States contains extensive canal systems that transport water for hydropower generation. Nuisance plants, including algae, grow in these systems and reduce their hydraulic capacity by displacing water and increasing surface friction. The most common solution to nuisance plant growth problems is applying chemical-control agents, which are often applied in an ad hoc fashion. This type of treatment is expensive, introduces chemicals into the ecosystem, and presents a potential long-term liability to businesses.

This report describes the results of a multi-year study performed in collaboration with Pacific Gas \& Electric (PG\&E) to investigate algal growth problems in their canal systems, and to evaluate various control methodologies. Three types of controls were selected for testing and evaluation including mechanical, biological, and chemical treatment. As part of this study, water quality data were collected and algal communities were sampled throughout the distribution system at regular intervals.

The Tiger Creek and Drum Canal systems located in the Sierra-Nevada mountains of central California were chosen for this detailed study. The water in these systems is very soft with very little buffering capacity and low nutrient content. The alga Ulothrix zonata was dominant in the algal community from the Tiger Creek Canal, and the diatom Didymosphenia geminata was the primary alga associated with the problems encountered in the Drum Canal. Both species are frequently found in cool water with low nutrient content.

While this study resulted in the development of a more complete physical and chemical data base for addressing algal control problems in these systems, it also pointed to the need for more continuous monitoring of canal conditions in order to predict the optimum timing for the application of control procedures. In particular, were indications that some parameters, if tracked more closely, might allow operators to track and predict the onset of algal growth.

Temperature, for example, could be useful in determining when algal blooms are likely to occur. The study indicated that temperatures below $10^{\circ} \mathrm{C}$ kept the algae in a dormant or less-active growth state. Water $\mathrm{pH}$ was another parameter that might provide insight into the development of algal problems in these systems; some subtle changes were seen in the water chemistry data. Sunlight may also play a critical role, since the algal growth problems typically occurred from early May through late October when the sun reaches its maximum height over the canal. 


\section{ACKNOWLEDGMENTS}

The authors acknowledge the assistance of all participants in this two year effort. Initial action was based on interactions between Ted Rasmussen (Hydropower Program, Lockheed Martin Idaho Technologies), and Shane Bhattacharya (Hydro Generation, Pacific Gas \& Electric). We thank them for getting the ball rolling. Gerold Sommers and Shirley Sandoz are also acknowledged for recognizing the importance of the work and overseeing the development of the research plans and other activities. We also thank Mr. Paul Grahovac for his help in setting up the Cooperative Research and Development Agreement (CRADA No. 96-CR-01) between LMITCO and PG\&E. Paul took the task upon himself to resolve many issues in the development of the CRADA. He demonstrated perseverance and fortitude in accomplishing this task.

We also thank Donna Lindquist (PG\&E-Research and Development) for helping formulate the research activities and for contributing as the principal developer of the Decision Matrix used to evaluate alternate algal control treatment methods. A great deal of gratitude is expressed to all who helped in the field work; Keith Heimbach (PG\&E-Tiger Creek Powerhouse), and Bill Tomei, (PG\&E-Mother Lode Hydro), were instrumental in allowing us to access the Tiger Creek Canal system and provided reviews of proposed research activities. Arie Foster helped collect water samples and background data on numerous occasions and many times provided assistance beyond the normal range of his work assignments. Don Bartel (Sierra Consultants Inc.), was a tremendous help in collecting field data during the 1996 research period. Don not only completed a lot of the foot work, but was responsible for the establishment of sample site locations on the Drum Canal.

We thank other industrial partners ${ }^{\mathrm{a}}$ who shared their algal control expertise and assistance during this program.

- Shannon Harris - EarthTec, Environmental Science

- Jason Frank - MicroForest, Inc.

- Joe Solga - Elf Atochem, Inc.

This work was completed under the U.S. Department of Energy, Idaho Operations Office Contract No. DE-AC07-94ID13233. their products. 


\section{CONTENTS}

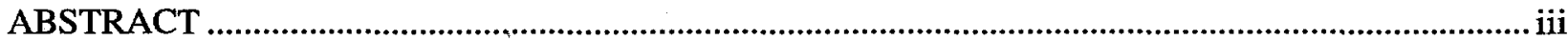

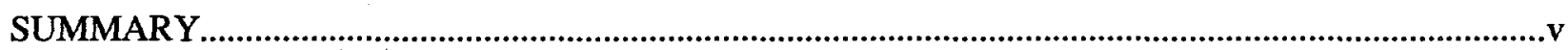

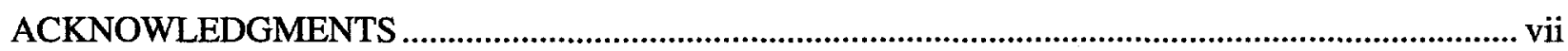

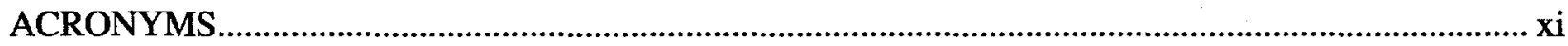

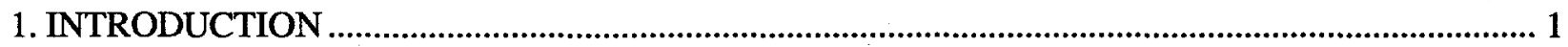

2. BACKGROUND

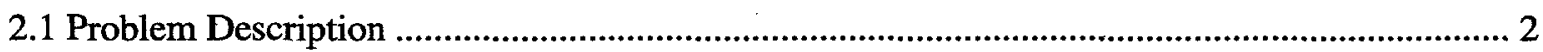

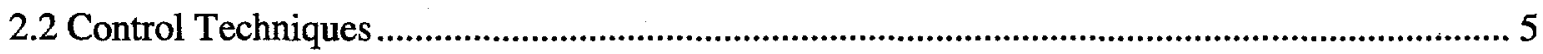

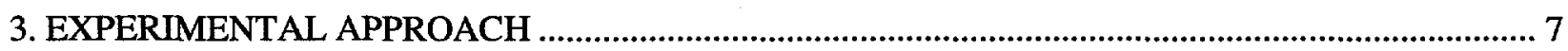

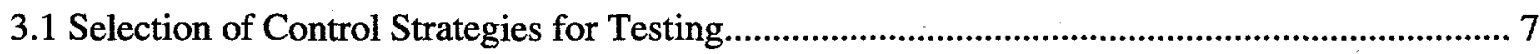

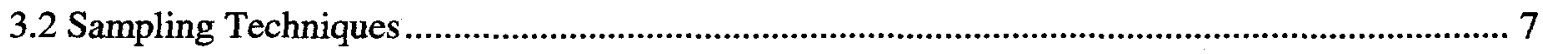

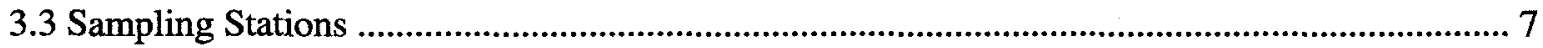

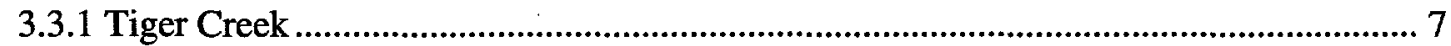

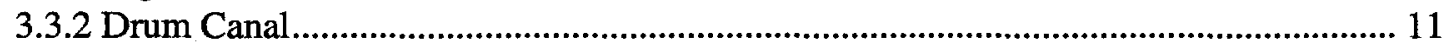

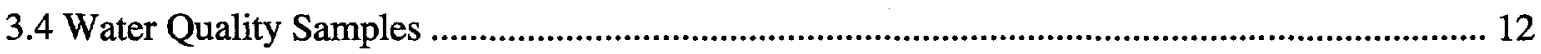

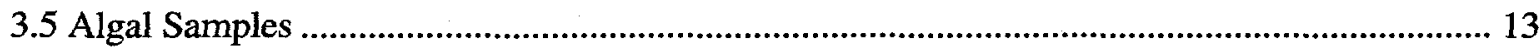

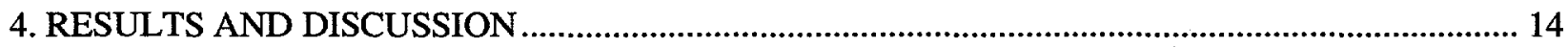

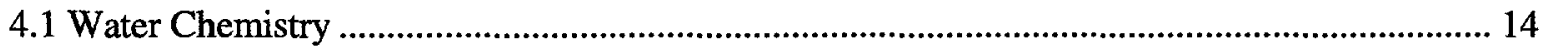

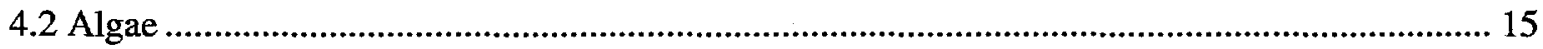

5. ALTERNATE CONTROL STRATEGY INVESTIGATIONS ................................................. 18

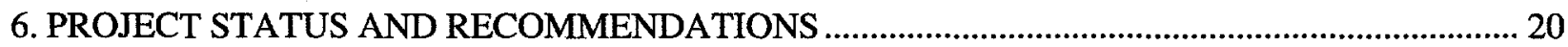

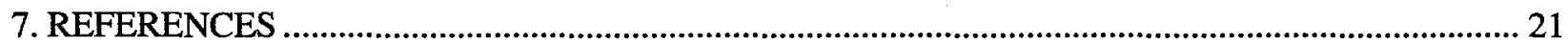

Appendix A-Bibliography 
Appendix B-Water Quality Data

Appendix C-Decision Matrix

\section{FIGURES}

Figure 1. Tiger Creek Canal - Long View ......................................................................... 2

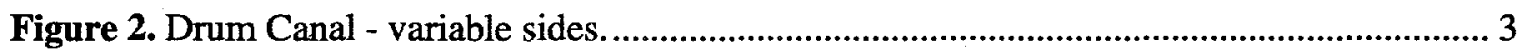

Figure 3. Charts of stages of algal growth and impact on water flow..................................... 4

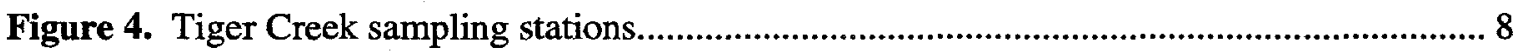

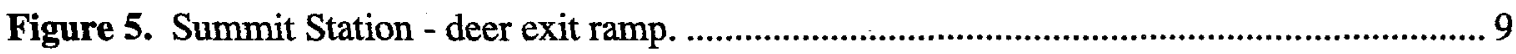

Figure 6. Regulator Reservoir (R/R) Pool, fish release (FR), and other sampling stations....... 10

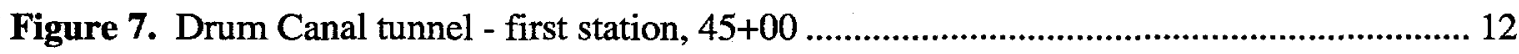

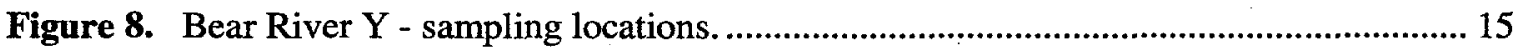

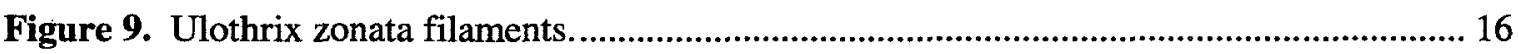

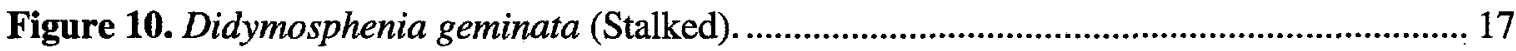

Figure 11. Holdfast cell - Ulothrix zonata....................................................................... 19

TABLES

Table 1. M3 Algae Preservative. 


\section{ACRONYMS}

INEEL Idaho National Engineering and Environmental Laboratory

PG\&E Pacific Gas \& Electric

R/R Regulator/Reservoir

RC Road Crossing

THM Triholomethanes 


\section{Aquatic Plant Control Research}

\section{INTRODUCTION}

Western water resources continuously face increased demand from industry and the public. Consequently, many of these resources are required to perform multiple tasks as they cycle through the ecosystem. Many plants and animals depend on these resources for growth. Algae are one group of plants associated with nutrient and energy cycles in many aquatic ecosystems. Although microscopic in size, most freshwater algae are capable of dominating and proliferating to the extent that waters resource value is compromised for both industrial and domestic needs. For example, nuisance algal growth may cause taste and odor problems in domestic water supplies. Filamentous algae may reduce lake and stream access to fishing, swimming, or other recreational activities. In some cases, the algae may be toxic and threaten the health of wildlife, livestock, and humans. In industrial processes, algae may impact operational productivity by clogging water intakes, reducing heat transfer, or interfering with the control of chemical reactions. In economic terms, the impact of nuisance algae is a multi-billion dollar per year problem.

The Northwest region of the United States contains extensive canal systems that transport water for hydropower generation and agricultural irrigation. Nuisance plants, including algae, that grow in these systems reduce their water transporting efficiency. The most common solution to nuisance growth problems is the application of chemical-control agents. This type of treatment is expensive, introduces chemicals into the ecosystem, and presents a potential long-term liability to businesses.

This report describes a multi-year study performed in collaboration with the Pacific Gas \& Electric Company (PG\&E) to investigate both algal growth in their canal systems and various control methodologies. As part of this study, water quality data was collected and algal communities were sampled throughout the distribution system at regular intervals. The purpose of this study was to develop a more complete understanding of conditions leading to algal blooms, a better informed selection of treatment plans, and improved techniques for evaluating the effectiveness of control strategies. The ultimate goal of the work was to develop cost-effective, environmentally sound, long-term management strategies for the prevention and control of nuisance algae. 


\section{BACKGROUND}

\subsection{Problem Description}

The Tiger Creek Canal system (Figure 1) was built for power generation in the early 1930s. The Tiger Creek Canal originates from the tailrace of the Salt Springs Powerhouse. The Salt Springs Powerhouse has two units: one receives water from the Lower Bear Reservoir, and the other receives

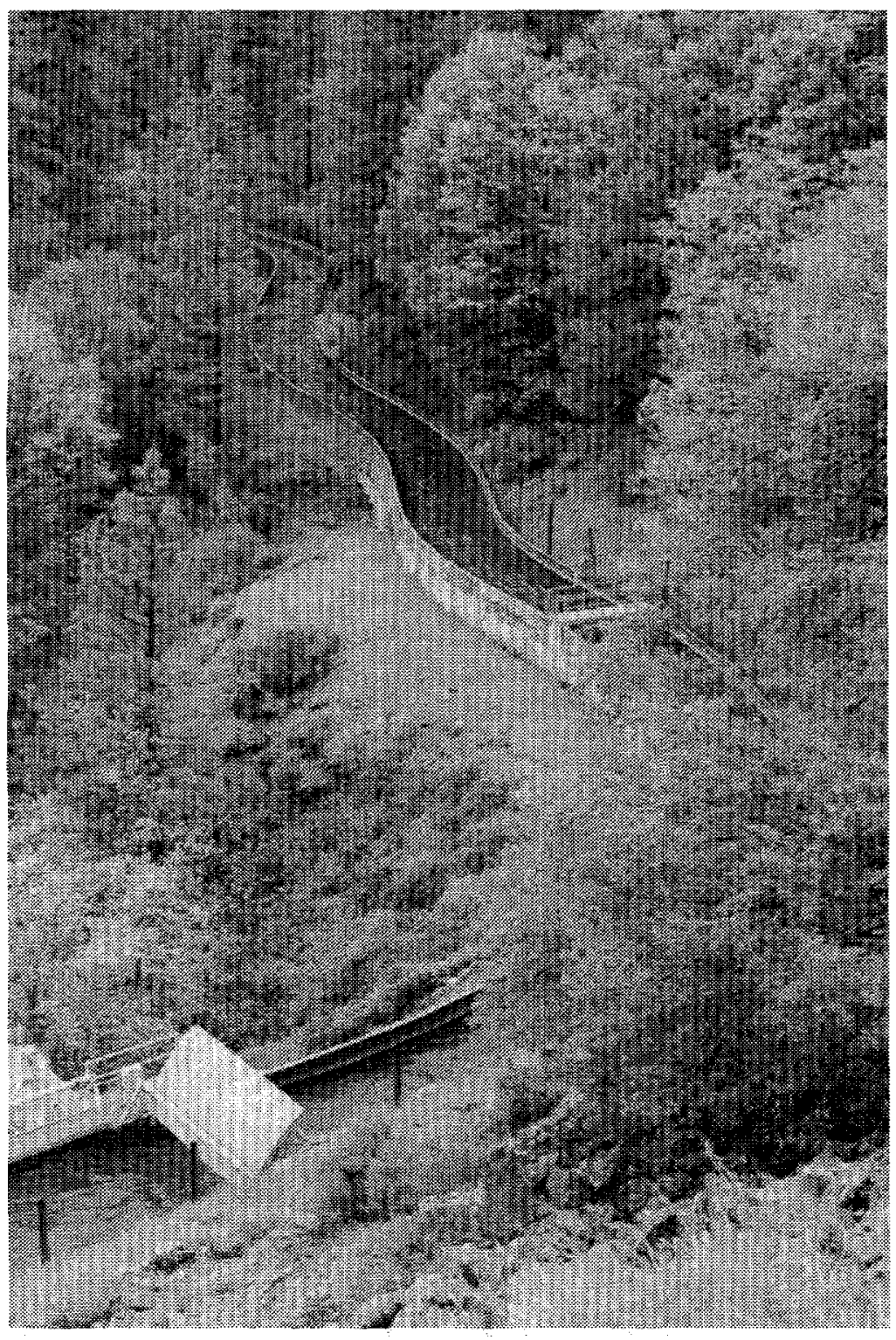

Figure 1. Tiger Creek Canal - Long View water from the Salt Springs Reservoir. Both are in the Sierra Nevada Mountains, in the Mokelumne River Basin. The drainage comes from granite bedrock with low human impact, that is, little development, low recreation use, and minimal forestry activity. The water is very soft, slightly acidic, and low in nutrients. Flow in the hydro-generation canal is maintained at the maximum capacity of 550 cubic feet per second (cfs). The canal is approximately 17 miles long, and is made up of concrete box sections 14 feet wide, and seven feet high. The water depth is about six feet with one foot of freeboard. The flow velocity is approximately seven feet per second $(\mathrm{ft} / \mathrm{s})$. In addition to the main canal, there are seven tunnels and two reservoirs associated with the general flow of the canal. The first reservoir, Regulator Reservoir, has a surface area of approximately 13 acres. This reservoir receives water from the upper 15 miles of the Tiger Creek Canal, as well as from the Tiger Creek proper, and serves as a main reserve for the feed flow into the second reservoir, the Tiger Creek Powerhouse Forebay. This reservoir has an approximate surface area of two acres and feeds directly into the Tiger Creek Powerhouse penstock.

Although the flow in the canal primarily originates from the Lower Bear and Salt Springs Reservoirs, there are a number of locations along the canal where water can be discharged from or added to the canal flow. Points of discharge are used to eliminate water from the canal due to emergencies such as blocked flow from fallen trees, rocks, etc. Inputs are used to supplement the canal flow during periods of low runoff and are associated with the major streams throughout the basin area. 
During the 1996 season, the area of study was expanded to include the Drum Canal, a 9 mile long hydropower generation canal system beginning at a tunnel from Spaulding Reservoir along the South Yuba and ending in the Drum Forebay. The drainage is also from granite bedrock, with little nutrient content and low buffering capacity. The water may be characterized as very soft with a carbonate hardness of approximately $25 \mathrm{ppm}$. The canal varies both in breadth and depth. Typically, flow in this canal is maintained at approximately $775 \mathrm{cfs}$. The canal surface is a Gunite material that has been sprayed onto the natural and constructed structures that define the canal channel (Figure 2). The forebay is a large pool, approximately 23 surface acres, that discharges through two separate intakes to Drum 1 and 2 powerhouses. The discharge pool is the forebay for Dutch Flats 1 and 2 powerhouses, the next in a series of impoundments along the Bear River used for hydropower generation.

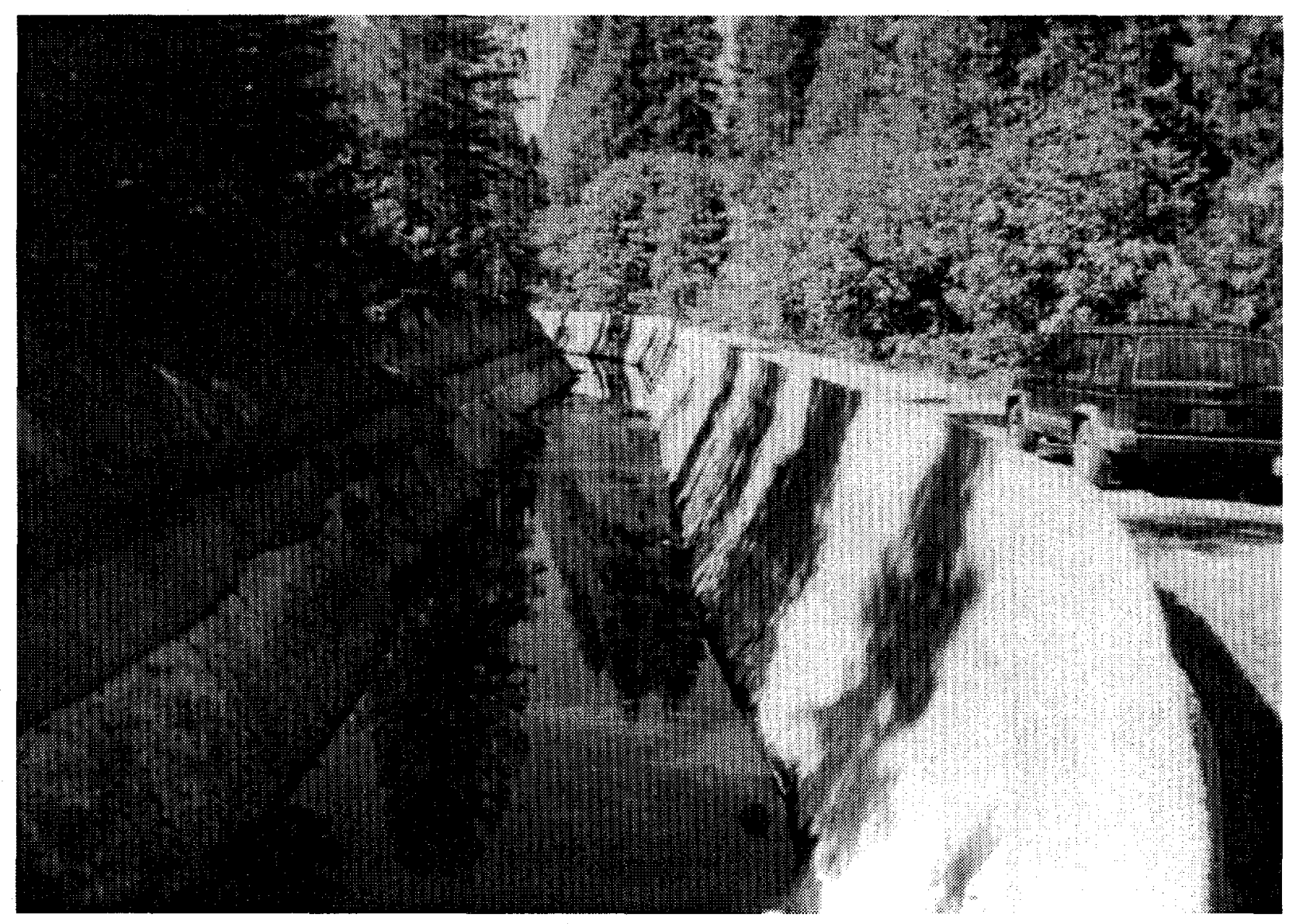

Figure 2. Drum Canal - variable sides.

In both canal systems, growth of filamentous algae impedes the ability to maintain the required canal flow to meet power-generation requirements. The development of algae in these canals displaces the volume of water that they can deliver to the powerhouse. Algae typically grows anchored to the bottom and sides of the canal. The extended filaments also change the flow characteristics around them, increasing the drag on the water. As the water slows, the faster-flowing water rides higher in the canal, over the slower- moving water near the bottom. This causes the water in the canal to ride higher, approaching the tops of the canal sides (Figure 3). In order to maintain a safe canal height along the sides of the canal, the powerhouse operator reduces the amount of water discharged into the canal to restore the freeboard. 


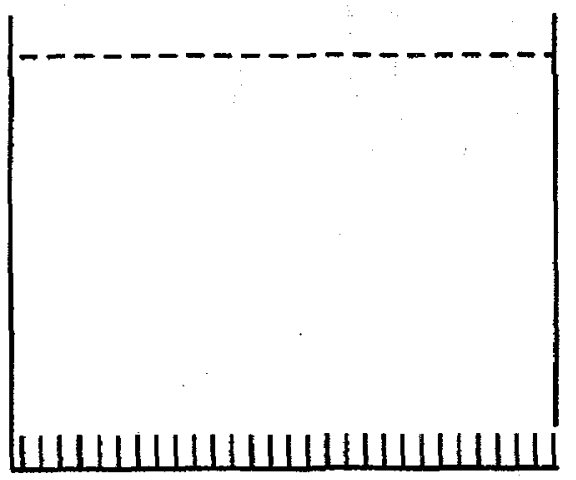

Normal Canal Flow

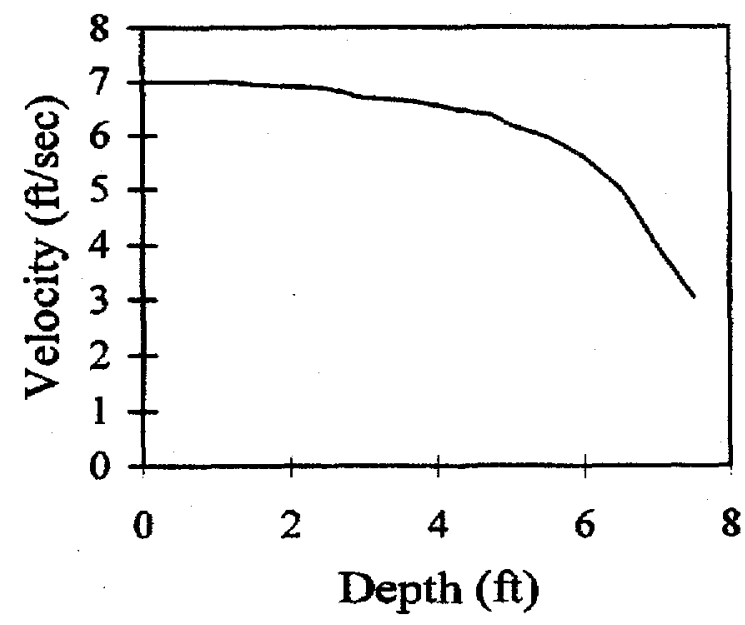

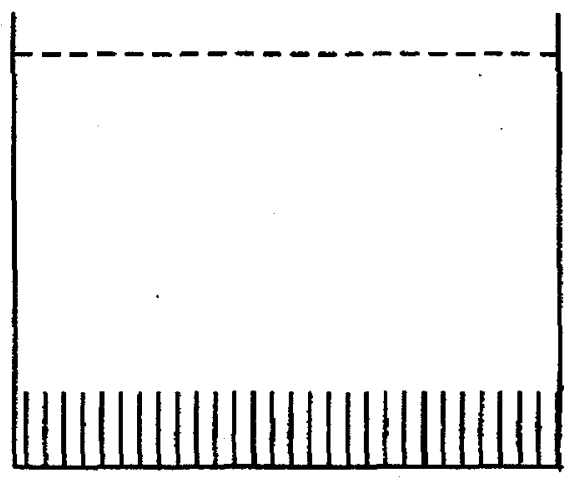

Canal Flow with Algae

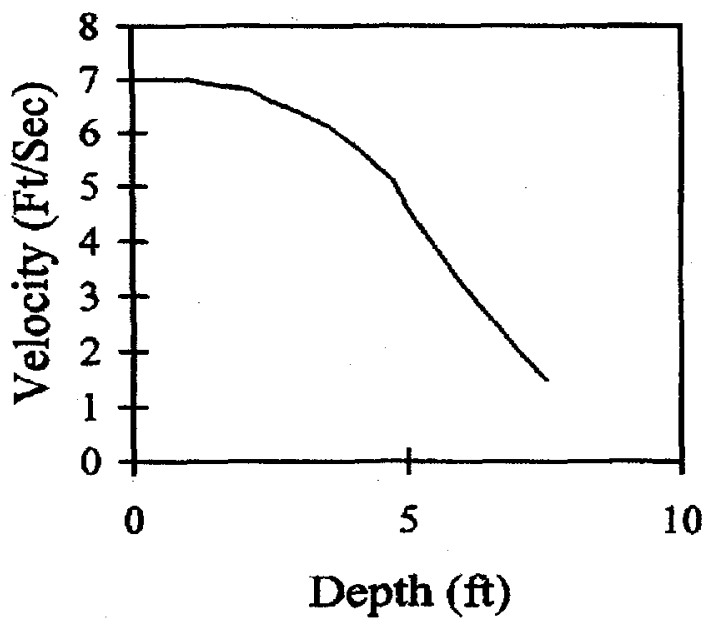

Figure 3. Charts of stages of algal growth and impact on water flow.

Less water flowing through the canal means less water to replenish the water discharged to the powerhouse to generate electricity. As the algae continue to grow and develop into longer filaments and greater biomass, their interference with the canal flow increases. Eventually, flow is reduced to such an extent that it threatens the ability to maintain reservoir volume in the forebay to meet generation demands. Typically, just before this point is reached, a decision is made to take the canal out of service and perform a clean-up. In addition to impacting flow rate and volume, the algae in the Drum Canal also clogs collection screens and control gates. A massive amount of the stalked diatom collects on these structures often resulting in damage as well as functional impairment.

The two standard techniques used to clean canal systems are hydro-blasting and chemicals. The method typically used to clean the Tiger Creek Canal is hydro-blasting. In this procedure, the canal is 
drained, exposing the sides and bottom and a truck, equipped with high pressure water jets, is driven through the canal dislodging and washing out the algae. Chemicals are typically used to control algae in the Drum Canal.

While effective in removing the algae, these techniques are expensive. In addition to the lost generation capacity while the system is down, there are costs associated with the manpower and materials incurred to perform the work. Typically, it requires two days to hydro-blast the entire Tiger Creek Canal and an additional two days to dry the canal; it has been determined that the extra days of drying significantly delay regrowth of the algae in the canal. Unfortunately, this treatment method needs to be repeated several times during the active algal growing season, which normally begins in early May and continues through October. Consequently, alternative methods for algal control have been sought over the last several years.

\subsection{Control Techniques}

There are four general methods for controlling algal growth; chemical, biological, mechanical, and combined control incorporating two or more methods. In addition, these techniques may be implemented in an intermittent, continuous, or a multiplexed fashion. A brief description of each method is presented below. For additional information refer to the Bibliography under the Overview Section in Appendix A.

Chemical methods are often selected to control algae because they are easy to apply on an as-needed basis. The most widely applied chemical is copper, or a copper compound. In order to properly use any chemical treatment procedure, the basic water chemistry must be known so that an effective dose concentration can be calculated. Chemical agents may be sensitive to water hardness, acidity, and particulate loads in the application area. Some materials interact with other components in the system, potentially increasing their toxicity. Also, the general persistence and form of the chemical should be considered. Some of the newer herbicides are designed for specific, short-duration control. This type of treatment requires repeated application, but has the advantage of lowering the long-term environmental effects.

Biological control agents are based on the activity of living organisms or pathogens. The activity may be a direct or indirect action; for instance, the use of algal-eating fish, snails, macroinvertebrates or other animals is considered a direct action. ${ }^{7}$ Similarly, bacteria, fungi, and viruses may infect or parasitize algae resulting in their death. The indirect activities of some organisms may also control or eliminate algae. For example, some fish create an increase in the suspended solids in the water column, reducing light penetration to the bottom sediments, thereby decreasing algal growth. Other microorganisms may produce proteins, enzymes, or compounds that reduce algal growth. The fast flow ( $7 \mathrm{ft} / \mathrm{s})$ in the Tiger Creek Canal system prevents the use of conventional biological control agents such as fish or macroinvertebrates.

Mechanical control methods involve the physical scraping, dislodging, raking, and removing of biomass. Various configurations of mechanical techniques have been developed to eradicate algae within water conveyance systems. Mechanical methods have the advantage in controlling growth in isolated regions and environmentally sensitive habitats. In the Tiger Creek Canal, water blasting has been the predominant means of removing and controlling algae.

Combining algal control techniques has not received much attention, but appears to have great potential. ${ }^{14}$ In fact, previous research at PG\&E with chlorine, hydrogen peroxide, and other chemicals, in combination with water blasting and desiccation, have resulted in algal control for longer periods than 
application of single control procedures. ${ }^{89}$ Also, recent studies indicate that control may be achieved through the combination of new chemical and mechanical procedures.

In addition to the method of control used, the manner of its application must also be considered. Some products or techniques are most effective when applied continuously at a low level, once control is established. It is generally believed that this will keep bacteria, algae, and other microbes from producing a biofilm, initiating growth, and developing into a larger problem. This may generally be true; however, microorganisms express a degree of flexibility and may be able to develop a resistance to chemicals when exposed on a continuous basis over a period of time. Or, there may also be a change in the dominant component in the biological community. Usually when a biological niche is vacated, it opens an area for another organism to invade and occupy. The new dominant species usually expresses some resistance to the control measure, and consequently, presents a new nuisance growth problem.

Treatment on a periodic or as-needed basis is generally applied in conjunction with some type of monitoring to determine when applications are required. The monitoring may be accomplished by direct physical observations or by various types of instrumentation. The downside of this method is the difficulty in stopping and controlling growth once it is established. Another problem with this approach is that intermittent treatments typically requires higher application concentrations to initiate control, reverse the growth, and then maintain stability. This type of control increases the chance of releasing fugitive chemicals from the application site.

In addition to either continuous or intermittent treatments, multiple or combined chemicals may be used. This type of control is instituted when there is concern about using a particular material for an extended period of time. Nuisance species may build up resistance to the chemical(s) allowing other, more resistant species to move in and eventually occupy a more prominent part of the benthic community, necessitating a change in the treatment strategy. 


\section{EXPERIMENTAL APPROACH}

\subsection{Selection of Control Strategies for Testing}

A methodology for selecting and evaluating algal control techniques was developed. In the selection process detailed in Appendix $\mathrm{C}$, a decision tree is used to evaluate different types of control strategies against common criteria including environmental risks, safety, impact to power production, and systems operation. The matrix was implemented by PG\&E, prior to the 1996 algal growing season, to select control practices for the summer's research period.

\subsection{Sampling Techniques}

Even though PG\&E has conducted numerous studies on the Tiger Creek Canal system, ${ }^{4,8,9}$ the information was fragmented, preventing the ability to draw specific conclusions about factors related to the algal growth problems. Therefore, a principal objective of this effort was to simultaneously collect water and algal samples to determine whether there were any correlation's between the different parameters measured and the algal problems observed.

\subsection{Sampling Stations}

During the 1995 and 1996 seasons, a number of station locations were selected to collect water quality and algal samples along the course of the Tiger Creek Canal system (Figure 4). These stations are listed in order from the top to the bottom of the canal system, and can be identified by their distance (100 feet) from the Regulator/Reservoir.

\subsubsection{Tiger Creek}

The Salt Springs Powerhouse $(940+00)$ tailrace spillway is adjacent to the powerhouse proper. Water from Salt Springs and Bear River Reservoirs flows through the Salt Springs Powerhouse and is discharged to the Tiger Creek Canal at this location. The volume of flow into the Tiger Creek Canal is regulated by a control gate at the head of the canal system. Excess water is discharged (spilled) to the Mokelumne River. Samples were usually collected by capturing water flowing over the spillway in a container, then transferring it to the appropriate sample bottles. Algae were collected by scraping the surfaces of the spillway, or any other structure in the area, exhibiting developed biofilm or algal growth.

The Salt Springs access ramp $(920+00)$ is located approximately 2000 feet downstream from the Salt Springs Powerhouse. Access ramps are concrete structures wide enough for trucks and other vehicles to drive into the canal. They are also an easy means of getting into the canal to collect water and algal samples. The high flow in the main section of the canal prohibits the collection of algae from the sides or bottom of the canal. Algal and water samples were collected from the mixing zone on the access ramps. 


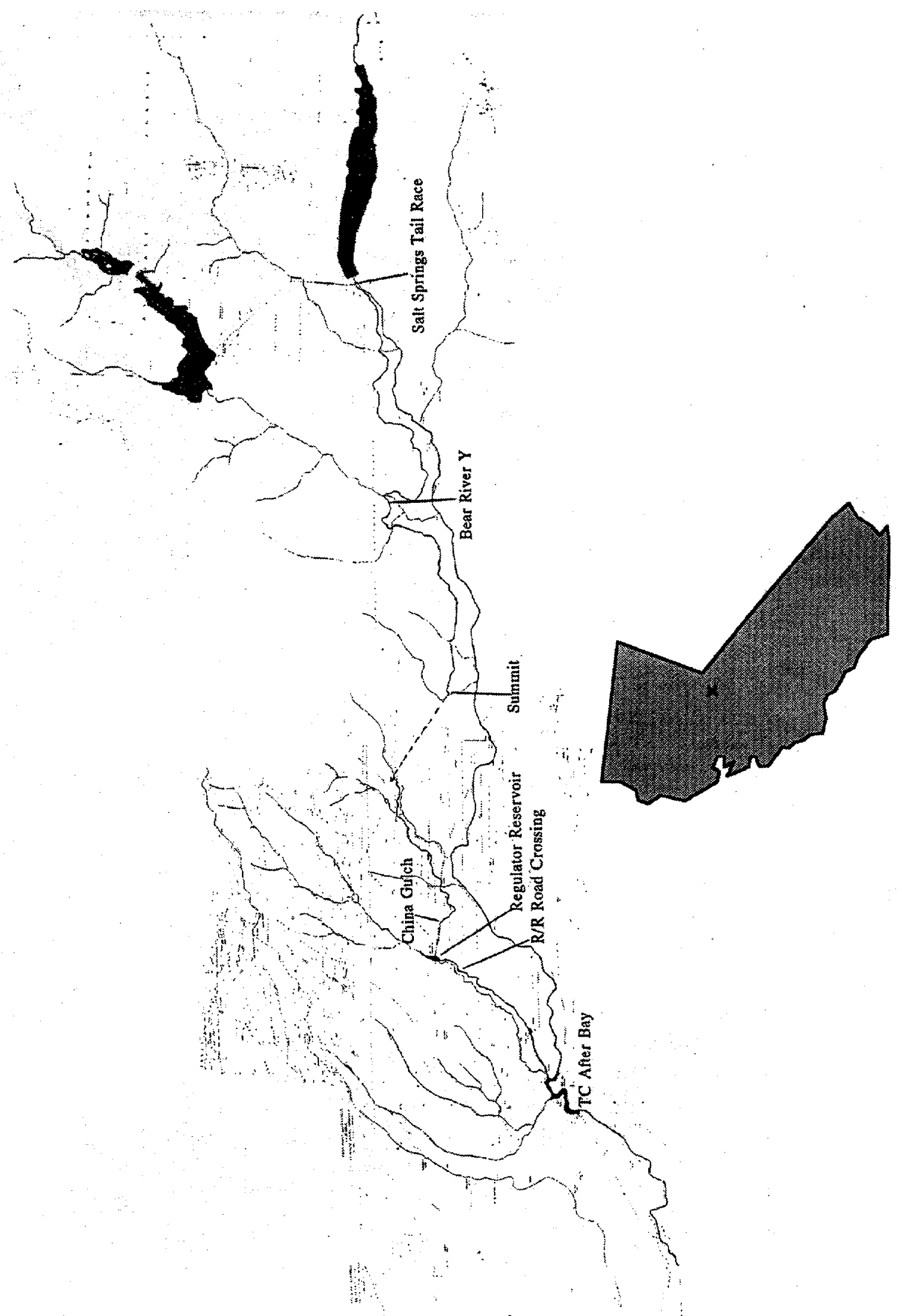

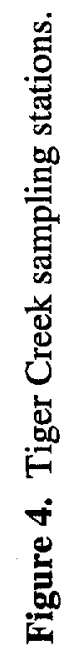


The Bear River Y $(640+00)$ station was located along the point where the Bear River flows from the Lower Bear River Reservoir and discharges into the Mokelumne River. This station had several unique features. Along the Bear River proper, upstream from the road bridge, there was a U.S. Geological Survey gaging station measuring the discharge flow of the Bear River. At the bridge, there are flow control gates that can be used to direct flow into the concrete feeder channel leading to the Tiger Creek Canal system. This concrete structure is approximately 150 to 200 yards long with additional gates and siphons, and meets the Tiger Creek Canal at an angle, thus lending to the name Bear River Y (Figure 8). This was a common point of sampling throughout the 1995 and 1996 seasons; however, the point of collection was not the same, but varied according to the time of sampling and the person collecting the sample.

The Summit $(340+00)$ station was located upstream of the entrance into Summit Tunnel (Tunnel \#3), a 1.5 mile tunnel that discharges into the continuing Tiger Creek Canal at East Panther Creek. At this location, there is a deer exit ramp that was used as the point for the collection of water and algal samples (Figure 5). The Green's Creek area, just upstream from the summit station, typically had the largest amount of algal growth. This section between the Bear River Y and Summit develops problems during the summer.

The East Panther Creek $(240+00)$ station, an access point on the other end of Summit Tunnel, has several structures that permit canal crossing and provide access to the inside of the canal. This station has the potential to siphon water from

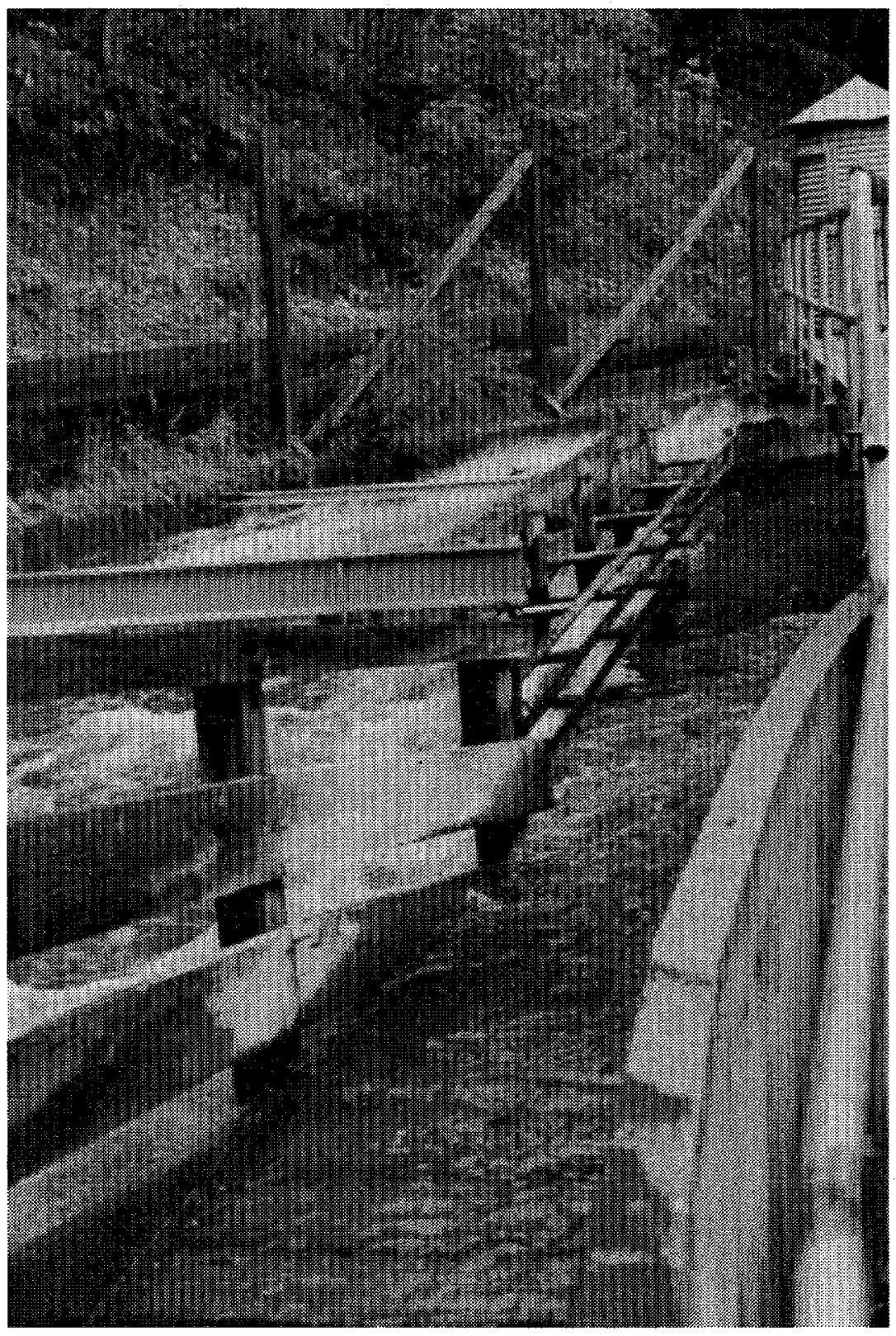

Figure 5. Summit Station - deer exit ramp. East Panther Creek. The intake, approximately 100 yards upstream from the canal, is used to supplement flow into the Tiger Creek Canal. East Panther Creek is typically a disposal point for algal biomass from canal washings that occur upstream between the Bear River Y and the Summit. 
The Deer Creek road crossing $(120+00)$ station, an easy access point near the China Gulch station, was used to collect water and algal samples when either China Gulch was missed or when time restraints occurred. There is a vehicle access ramp and deer escape at this station.

The China Gulch $(40+00)$ station was a point located just before a 2.6 mile tunnel (tunnel \#1) that discharges into the Regulator Reservoir. This station permitted the separation of Tiger Creek Canal conditions from influencing factors associated with the reservoir and Tiger Creek proper. There was an access ramp to the canal at this station that served as the point of collection for water and algal samples.

The Regulator Reservoir road crossing $(30+00)$ station was an access ramp to Tiger Creek Canal downstream from the Regulator Reservoir, and provided a measurement of reservoir discharge quality and the influence of Tiger Creek and the reservoir on algal communities. Samples were typically collected from the access ramp on the upstream side of the road crossing, or along the lower canal wall on the downstream side of the bridge.

Initially, interests were directed at measuring and distinguishing the differences between the water coming into the Regulator Reservoir, and the water leaving the Regulator Reservoir through the China Gulch tunnel and at the Regulator Reservoir road crossing.

During the 1995 research period, the need to define additional zones within the reservoir boundary became apparent. Prompted by problems that developed during a chemical treatment test on Tiger Creek Canal, and to determine whether the cause was related to the cumulative effects of chemical applications or decreased dissolved oxygen levels within the reservoir and its outlets during treatment periods, several additional points were sampled within the Regulator Reservoir on a regular basis (Figure 6).

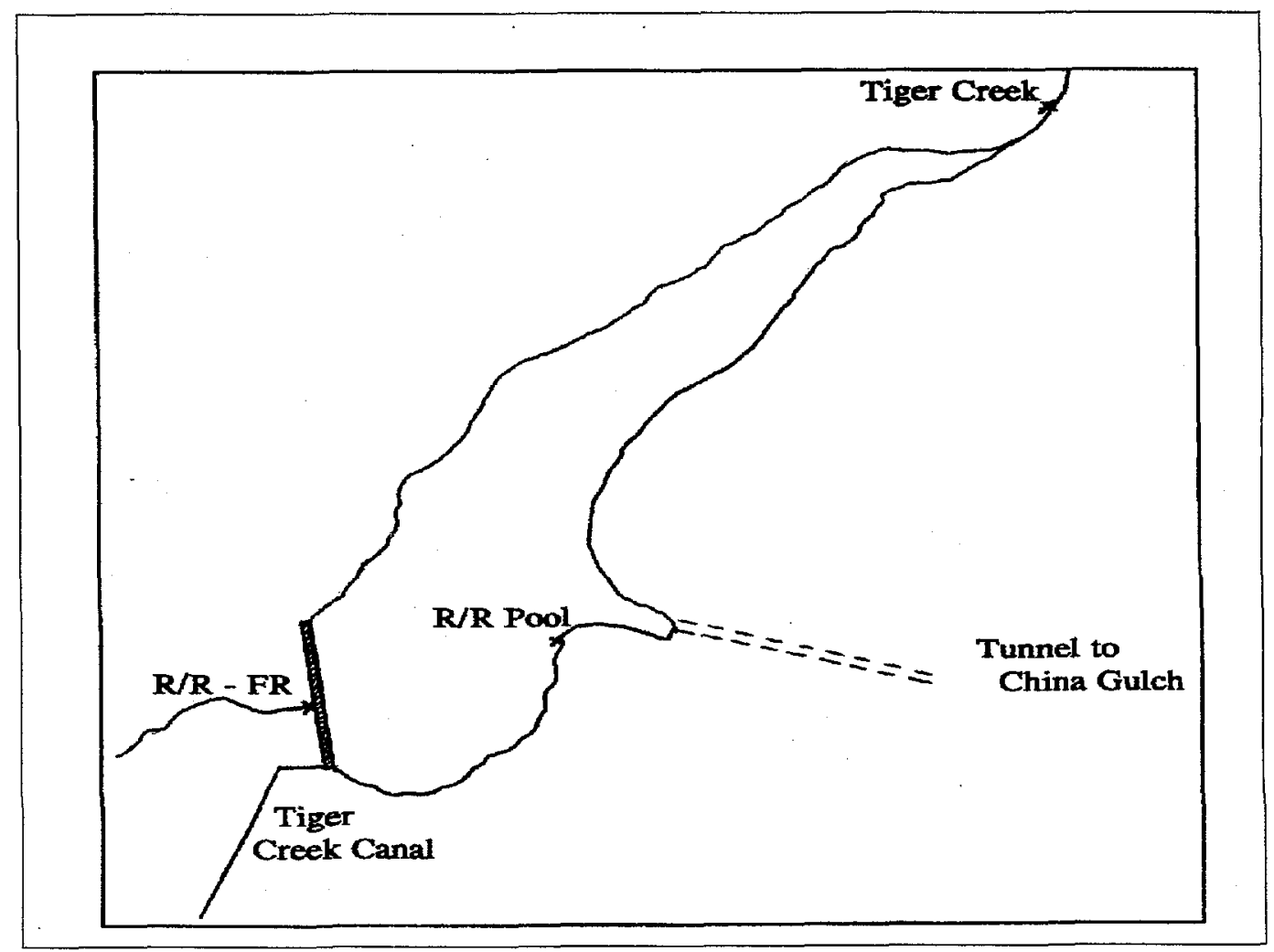

Figure 6. Regulator Reservoir (R/R) Pool, fish release (FR), and other sampling stations. 
The Regulator Reservoir Pool station was located at a small jetted piece of land near the out-fall of the water coming from China Gulch and represented the surface water. Here, water flows out of the tunnel, through a narrow channel, and empties into the body of the reservoir. The sampling point was near this mixing zone where water from the channel swirls around and back mixes with the reservoir. This station was chosen to represent the main pool of the reservoir (around 10 surface acres).

The Regulator Reservoir-fish release reservoir pool discharge, referred to as the fish release, is a point of discharge from the reservoir, on the back side of the dam. This release forms the continuation of the Tiger Creek proper with eventual discharge into the Mokelumne River near the Tiger Creek powerhouse. The intake for this discharge is approximately 20 feet below the normal pool level in the Regulator Reservoir. The sampling point was in the turbulent mixing zone at the point of release. There is a concrete structure at this discharge point making it convenient to cross the stream and sample.

Tiger Creek enters the Regulator Reservoir along the northern edge and represents a constant feed source for the reservoir. The creek is accessed by a foot path that starts at the Regulator Reservoir dam and runs along the northwest side of the reservoir. The samples were collected in the first part of the stream channel, separated from the reservoir, in which flow was observed.

The Tiger Creek Forebay (120+00) station was located at the pool area (around 3 surface acres) just prior to the penstock to the Tiger Creek Powerhouse. This area is 1.8 miles downstream from the Regulator Reservoir road crossing and served primarily as a checkpoint to determine water quality before discharge and mixing into the Mokelumne River. It was also used as an observation point to recognize any potential water quality problems prior to discharge to the penstock.

The Tiger Creek Afterbay station was located downstream, where discharge from the Tiger Creek Powerhouse mixes with the Mokelumne River and provides impoundment for the next downstream hydro-generation facility. The collection point was at the dam, on the pool side from a floating structure near the intake for the West Point Powerhouse. This station was approximately 0.75 mile downstream from the Tiger Creek Powerhouse discharge.

\subsubsection{Drum Canal}

The Drum Canal (approximately nine miles long) was selected to test two different types of copper compounds. Only five stations were selected to monitor water quality in this system (see Appendix B). Station locations were selected based on the distance from the point where treatments were applied; this was 45+00 (distance in 100 feet from the Spaulding Powerhouse) for all treatments initiated in 1996.

The first station, YB28, was located upstream at the point where water emerged from the Spaulding tunnel and flowed into the open Drum Canal (Figure 7). There is a cross-walk and drive access to this point. This station served as the upstream control, or pre-application station.

The second station, HYW20, was downstream from the point of application. This station was selected to provide an initial concentration of mixed chemical product, and as a representative point to determine the mixed concentration of chemical product added at YB28.

The third station, YB40 (410+00), was an intermediate point between the upstream stations and the siphon discharge into the Drum Powerhouse forebay. This station was selected to provide an indication of chemical product concentration as a function of distance of flow and contact with canal biomass prior to dilution in the forebay. 


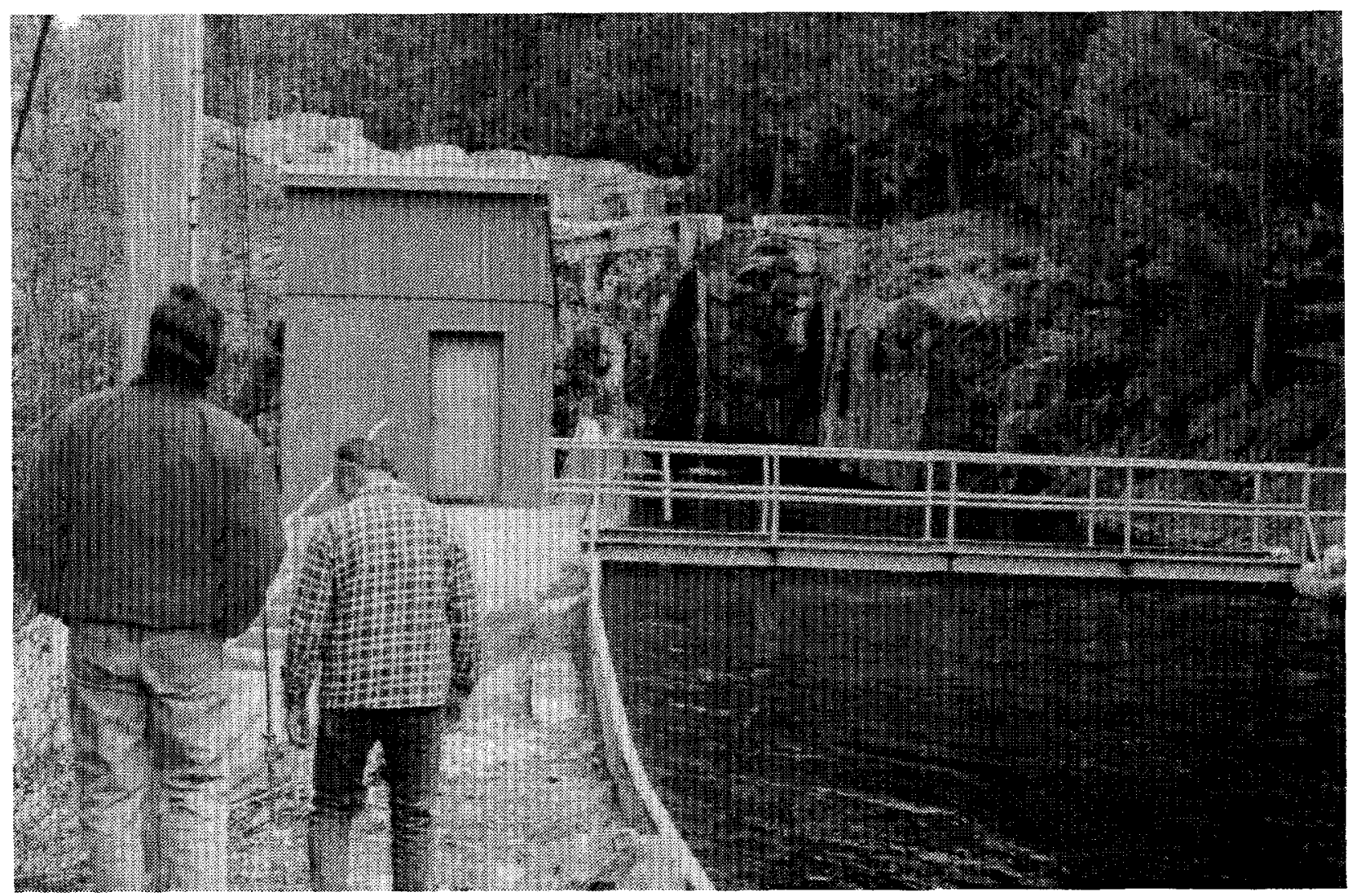

Figure 7. Drum Canal tunnel - first station, $45+00$

The fourth station, Drum Powerhouse Forebay, was located near the screen gate area for discharge into the penstocks leading to the powerhouse. This station provided an indication of how reservoir dilution effects the water it receives form the Drum Canal, in addition to indicating pool accumulation. The discharge from the siphons tends to create a circulation pattern in the forebay; discharge moves along the shoreline towards the control gates, then proceeds in a counter-clockwise pattern around the reservoir.

The fifth station, Drum Powerhouse Afterbay, was located at a point below the Drum Powerhouse where discharge from power generation mixes with water from the Bear River. This station indicated the dilution effects of the Bear River on conditions associated with the Drum Canal system.

\subsection{Water Quality Samples}

A number of parameters were measured to determine the water quality of the Tiger Creek and Drum Canal systems. Some of these measurements were conducted in the field while others relied on the collection, preservation, and transfer of samples to the laboratory for analysis. The conditions measured in the field were $\mathrm{pH}$, conductivity, temperature, and dissolved oxygen. The conditions measured in the lab were nitrate/nitrite/total nitrogen, total ortho-phosphorus, hardness, and copper. Note that not all 
parameters were measured during each sampling event. Copper was the basic component of the research interests in the 1995 and 1996 summer experimental programs. During the 1995 season, a hand-held instrument was used to measure $\mathrm{pH}$, conductivity and temperature at the time of sample collection. This instrument was calibrated against standards and procedures in accordance with U.S. Environmental Protection Agency's Guidelines and Standard Methods for the Collection and Measurement of Water and Waste Water Samples. The samples collected for laboratory analysis followed similar procedures for collection, preservation, and handling.

\subsection{Algal Samples}

Since it was not possible to collect algae from the canals while they were under full flow, algae were collected at the water/air interface along the canal walls and at points where access was permissible. Algae were collected at each station at the same time water samples and water quality parameters were measured. The algae were placed in sealed bags, packed on ice, and shipped to the Idaho National Engineering and Environmental Laboratory (INEEL) for observation and identification. In the lab, the samples were split; one part was preserved using M3 fixative (Table 1), while the other portion was refrigerated and maintained at $4^{\circ} \mathrm{C}$. Both live and preserved samples were used to identify alga's genus and species when possible. Part of the unpreserved sample was cleaned for diatom analysis using the boiling acid method. ${ }^{3}$ Also, the unpreserved samples were used to culture algae for studies at the INEEL.

Table 1. M3 Algae Preservative.

\begin{tabular}{cc}
\hline Reagent & Amount \\
\hline Iodine (crystal) & $1.0 \mathrm{gm}$ \\
Potassium Iodide & $0.5 \mathrm{gm}$ \\
Glacial Acetic Acid & $5.0 \mathrm{~mL}$ \\
Gluteraldehyde & $25.0 \mathrm{~mL}$ \\
Water & $100.0 \mathrm{~mL}$ \\
\hline
\end{tabular}

In addition to the algae collected at the time of water quality sampling, an effort was made to collect algae throughout the Mokelumne River Basin above Tiger Creek Powerhouse and determine the relative distribution of species within the system. For the purposes of this study, the basin was defined as beginning at the Salt Springs Reservoir and continuing along the canal to the point of discharge into the Mokelumne River below the Tiger Creek Canal Powerhouse. The major interests were in streams that served as potential sources of water for Tiger Creek Canal; Cole Creek, Bear River, Beaver Creek, East Panther Creek, Tiger Creek and the Mokelumne River. Algae were collected through all seasons over the two year period to determine their relative composition and possible influence on the algal flora of the Tiger Creek Canal system. In addition, algal samples were collected from a variety of habitats within the general basin area. These samples were prepared in a similar manner to Tiger Creek Canal station algal collections, except live specimens were not usually maintained.

Algae collected from the Drum Canal was confined primarily to the stations along the canal. Samples were collected in 1996 only. The protocol for collection, handling, and analysis were the same as those used for the Tiger Creek study. 


\section{RESULTS AND DISCUSSION}

\subsection{Water Chemistry}

A compilation of the water quality analyses is presented in Appendix B, "Water Quality Data." One of the most interesting findings from the water samples analyses, from both the Tiger Creek Canal and Drum Canal systems, was the lack of nutrients in the water. When algal biomass accumulates in sufficient quantity to interfere with water flow, it is generally assumed that the biomass is supported by an abundance of nutrients such as nitrogen and phosphorus. However, both drainage systems originate in basins with granite bedrock, soils low in mineral or organic content, and areas with low human impact. Consequently, the water quality data indicate very low hardness, no buffering capacity, low nitrogen, low phosphorus, and slightly acidic water quality. Total nitrogen and total phosphorus content ran consistently below detection limits of $5 \mathrm{ppm}$. Even when the analytical technique was changed to increase the sensitivity of the analysis, phosphorus content was only slightly above the detection limits of $10 \mathrm{ppb}$. Also, water quality parameters showed very little change throughout the summer, PG\&E's primary nuisance algal growing season.

One of the key analysis elements was to relate water chemical parameters to the guidelines for application of chemical-control agents. The toxicity of these products is often related to other components of the body of water to which they are applied. In the case of copper, the toxicity of copper changes dramatically in relation to water hardness. At low carbonate hardness, copper may be toxic, even at low application concentrations $(30 \mathrm{ppb})$. As the hardness increases the potential for the copper to complex with other minerals in the water column increases; therefore, it becomes less toxic and may be applied at higher concentrations.

During this period of analysis, it was determined that the canal system water is nutrient poor, cold $\left(\leq 12^{\circ} \mathrm{C}\right)$, and slightly acidic $(<6.5 \mathrm{pH})$ with low buffering capacity and specific conductivity.

During the 1995 testing of EarthTec, (a copper sulfate based algal control agent developed by Earth Science Laboratories, Inc., Arkansas, USA), there was considerable interest in how the copper would be distributed throughout the Tiger Creek Canal system. Copper sulfate had been previously used in the canal system to control algal, ${ }^{4}$ and there were some indications that copper had been deposited in the sediments of the Regulator Reservoir. Since EarthTec is a highly chelated copper compound, there was also an interest in whether the chelator would interact with any copper in the sediments, resulting in higher soluble copper concentrations below the Regulator Reservoir. During the initial 1995 test, there was a slight increase in the copper concentration below the Regulator Reservoir; however, this condition did not persist or reoccur, throughout the remainder of that summer, or in subsequent tests.

The water quality survey indicated that the overall water chemistry did not shift significantly throughout the 1995 collection season. Copper, introduced during various tests, decreased in concentration as it passed through the 17 miles of canal, and was diluted to well below discharge requirements $(15 \mathrm{ppb})$ when it mixed with the Mokelumne River. There was an increase in copper concentration observed in samples collected at the Bear River Y (Appendix B; Table 6). For this station, water samples were collected at different points along the $\mathrm{Y}$ by individuals participating in the sample collection process, primarily because of a miscommunicated station identification. It is also known that water samples were collected at points A, B, and C (Figure 8), and there are indications of turbulence and mixing where the Bear River feeder canal and the Tiger Creek Canal channels meet. It is believed that 
some of the variability in the copper concentrations seen for this area, may be related to the points where samples were collected along the $\mathrm{Y}$.

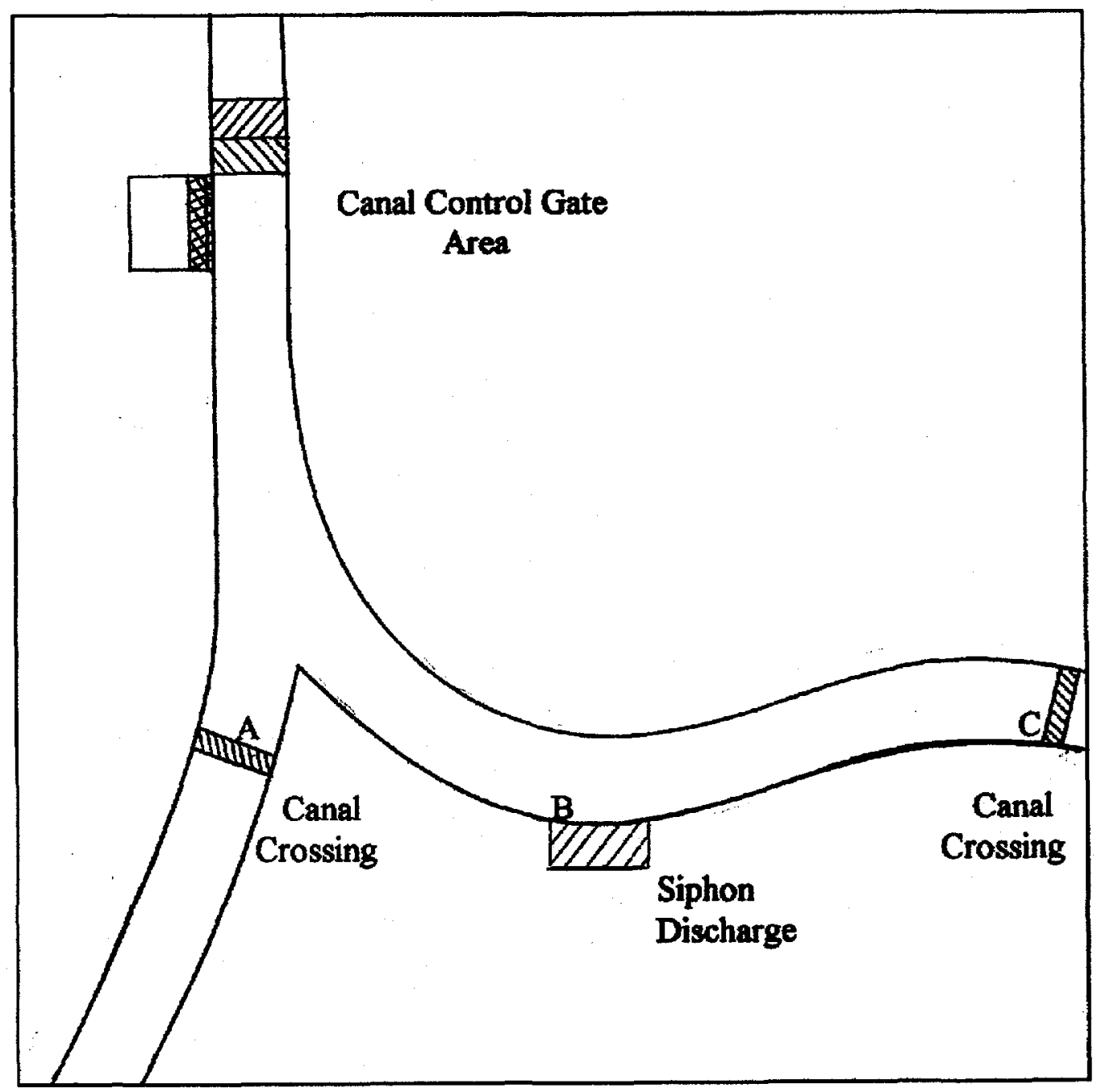

Figure 8. Bear River Y - sampling locations.

\subsection{Algae}

Disruptive algal growth in the Tiger Creek Canal system seems to be caused by two dominant forms. The most prominent species is Ulothrix zonata (Figure 9), a green, filamentous algae commonly found in cool waters of low nutrient content that are either ponded or flowing. Ulothrix is commonly found during the spring in the splash zones of the Great Lakes, shortly after ice cover is lost. ${ }^{15}$ It remains in this vegetative form until the water temperature rises, then it undergoes sexual division and becomes a swimmer cell that attaches to benthic substrates. It typically does not show extensive filament development until the water temperature lowers in the late fall, just before ice cover is restored. The 
filaments are typically 10 to 12 inches in length and are somewhat uniformly distributed across the bottom of the canal. In Tiger Creek Canal, the filaments do not grow on the sides of the canals only on the bottom. The canal has a 45 degree angled section, called the haunch, that separates the bottom from the sides. The filamentous algal growth stops right at the haunch and only a mixed blue-green algal and diatom biofilm exists on the sides of the canal. Additional algal forms are associated with the general biomass. Another green filamentous algae, Microspora sp., is commonly associated with the Ulothrix. Often bluegreen algae, both filamentous and colonial forms, are present in the biomass growing on the bottom and sides of the canal.

Diatoms may be in abundance, but typically make up less than $1 \%$ of the biomass in well developed Ulothrix growths. During the spring, below the Regulator Reservoir, filaments of Spirogyra grow and dominate the accumulated biomass in the canal. Also, during the mid-summer months a green, coenocytic algae, Vaucheria, grows in the canal and becomes very prolific, replacing the Ulothrix dominance.

Vaucheria attaches to the sides of the canal in addition to the bottom,

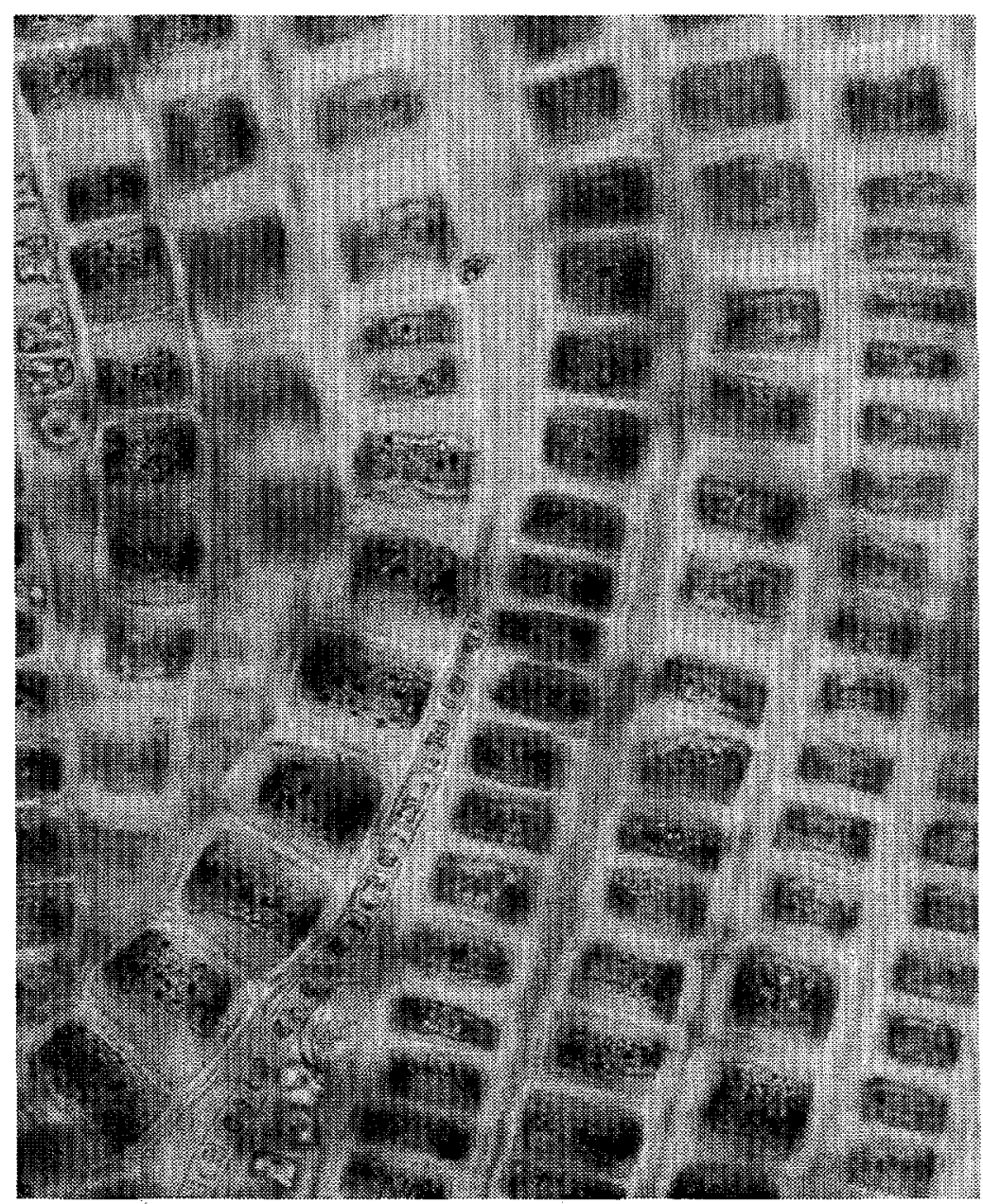

Figure 9. Ulothrix zonata filaments. has a very slimy texture, and has been found after copper treatment to control algae. It is not certain whether its appearance is purely seasonal, or whether it represents a potential tolerant species that replaces Ulothrix following copper application.

Algal samples were also collected throughout the Mokelumne River basin above the Tiger Creek Powerhouse. The composition of the algae in these samples mirrored the composition of algal forms found in the canal samples. The green filamentous forms could be found in different free-flowing streams, and similar communities of other algae. Blue-greens, and diatoms were also commonly observed in many of the samples. Where specific types of habitats were sampled, there were unique forms of algae present.

The Drum Canal had a problem with excessive growth of the diatom Didymosphenia geminata. This species had previously been identified in the Bear River and in the canal system below the Drum Powerhouse afterbay. Initial sightings, characterized this growth as a dense, off-white mat accumulating on the afterbay discharge screens. Due to its peculiar pink color, it was not thought to be an algal form. Since its first sighting, ${ }^{8}$ this algae has moved to occupy most of the Drum Canal, and has been collected 
from other hydro-generation canals in the area. Its growth characteristic has changed and now forms long, rope-like strands that reach several feet in length. Even though these strands decrease the ability to maintain flow in the canal, the biggest problem is caused by the collection of the algal biomass on the gates and screens in the hydro system. When this algae dislodges from its anchoring in the canal, it floats downstream and collects and packs on screens preventing the passage of water. The algal biomass tends to pack in tight densities making it difficult to remove from the structures. Typically, the canal system is drained under these conditions and the screens are scraped clean. When taken out of water the algal forms a bleached white mass that has a texture similar to that of cardboard. It is not easily torn and must be scraped to remove it from the screens. The algae is typically referred to as "killer algae" since its accumulation is devastating to the flow in the system.

Didymosphenia is a diatom in algae family Bacillariophyceae. It is typically found in cool water with low nutrient content. It is stalked; the actual cells produce a material that attaches to the substrate and then extend to lift the cell off the substrate into the water column (Figure 10). It is believed that this growth strategy permits the diatom to compete with other algae for both nutrients and light. ${ }^{5}$ Specimens with stalks several inches in length are typical. The stalk may also branch making it is possible to find several diatoms side by side sharing a common stalk for attachment. In the case of this diatom in the Drum Canal system, the stalks can become several inches in length. These stalks weave amongst each other to produce a rope-like material with considerable strength. Some of the broken strands collected from this system have been on the order of three or more feet in length.

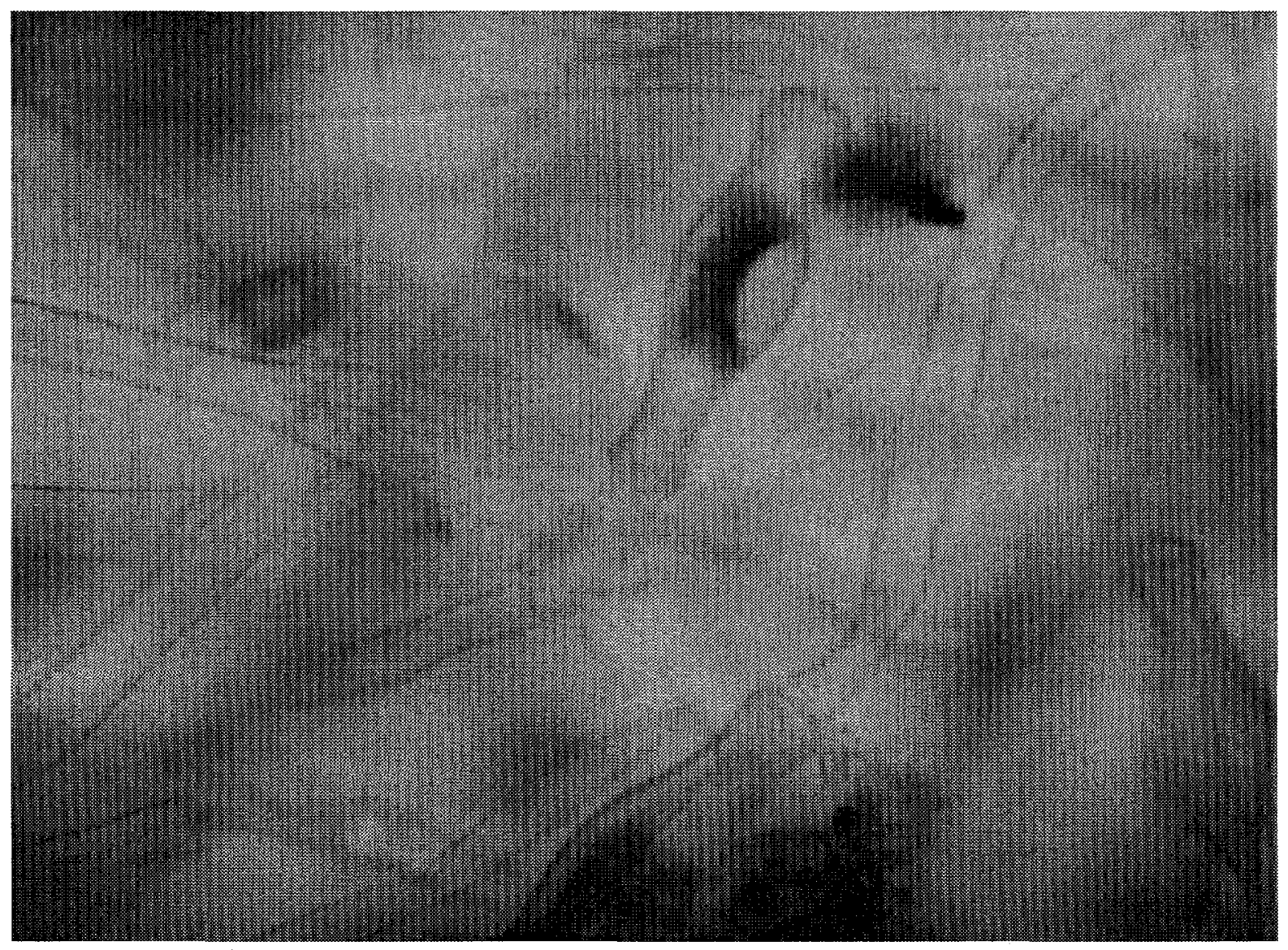

Figure 10. Didymosphenia geminata (Stalked). 


\section{ALTERNATE CONTROL STRATEGY INVESTIGATIONS}

As previously discussed, algae may be controlled with biological, chemical, or physical methods, or a combination of these methods. ${ }^{3}$ The use of chemicals (algicides) to control algae is a multi-million dollar business, and represents the most widely used technique. ${ }^{10}$ Chemical treatment methods are often selected because they are easy to use during preparation and application. Some of the more common chemicals used are halogens ${ }^{18}$ (chlorine and bromine), oxidizers (peroxides, permanganate), heavy metals (copper, zinc, cadmium, tin) and herbicides that tend to target photosynthetic pathways. ${ }^{4,7}$ These materials may work well in controlling algae; but, they possess the potential for negative side-effects. The halogens may form trihalomethanes (THMs) by complexing with organics; oxidizers are not persistent and may be corrosive to certain materials; herbicides may react with non-targeted aquatic plant life ${ }^{6}$; and, heavy metals are persistent in the environment.

The latter is one of the primary concerns with using copper to control nuisance algae. Copper sulfate has a history of use, and many industrial professionals have experience with the application procedures and regulations associated with this material. However, there is growing concern about its long-term use, its persistence, and its ability to concentrate and migrate through biotic and abiotic pathways in the ecosystem. It is most effective as an ion against algae; but, it may exist in several ionic states as it combines with present minerals and organic materials. Under the best of conditions, it is taken up by the target algae resulting in their death. It cannot be degraded beyond its elemental state, but remains in the environment; the property that poses long-term liability considerations for users. While copper sulfate is currently recognized and generally accepted as a control material for algae, future regulatory requirements may be different. Although too early to tell exactly which direction environmental interests are going, alternate chemicals and methods should always be a part of the development strategy for algal control and should not be overlooked even for immediate problems of relative short duration.

Recognizing that algae are primary producers and represent the basic component of many food webs, this research project began to develop baseline information in the pursuit of alternate algal control materials. Their cell walls are composed of carbohydrates, proteins, and other polymers that provide rigidity and strength to the cells. ${ }^{7}$ As the filament lengthens and cells mature, changes occur in the composition of the cells to provide the support needed for a longer filament. Some cells modify to become holdfast cells, with limited or no capability for photosynthesis, and modify structurally for attachment of the filament to the substrate (Figure 11). Our research was directed at understanding the changes that occur in filament composition during development. By understanding these changes, we may be able identify the processes by which cells are strengthened and modified. We can then develop materials to restrict or stop these processes, resulting in the control of attachment and filament length. This would preserve the growth of the algae to occupy its ecological niche but reduce the otherwise nuisance characteristics associated with attached, long filaments.

Algal materials analyses were begun to determine the differences in composition in relation to their position in an intact filament. Initial experiments were conducted to determine the relative carbon, hydrogen, and nitrogen ratios for different algal samples.

The production of agents to control algae during the fermentative degradation of barley straw ${ }^{19}$ was considered for testing this year, and an experiment was set-up on the Tiger Creek Canal. This process is based on the anti-microbial, anti-algal properties of a fermentative product produced by the decomposition of barley straw in a side stream digester (MicroForest, Inc., 1996). 


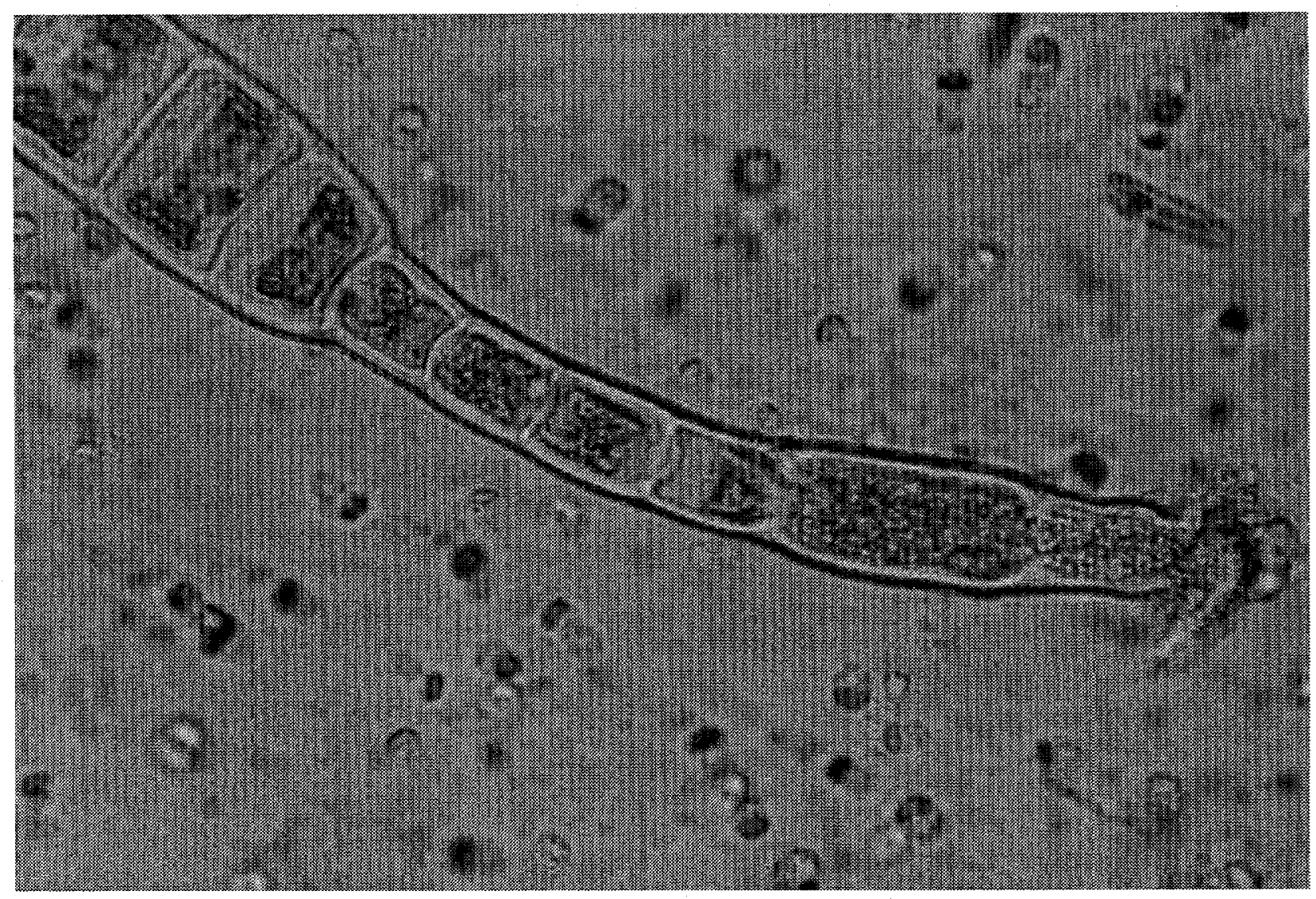

Figure 11. Holdfast cell - Ulothrix zonata. 


\section{PROJECT STATUS AND RECOMMENDATIONS}

The 1995 and 1996 studies on the Tiger Creek Canal and the Drum Canal resulted in a more complete physical and chemical database for addressing algal control problems in the systems. The study also indicated a need for more continuous monitoring of canal conditions in order to predict the optimum timing for the application of control procedures. Of particular interest are indications from the effort that some parameters, if tracked more closely, might allow operators to follow and predict changes in algal growth patterns. While the data collected is more complete than that previously assembled, it is generally believed that additional information is still needed to fully understand some of the events observed. The problem is, additional monitoring requires additional moneys to support the analyses and manpower.

Our investigations on Tiger Creek indicated that the following parameters may be useful to follow and predict changes in algal-growth patterns:

- Temperature: It seemed that early seasonal canal temperatures below $10^{\circ} \mathrm{C}$ kept the algae in a dormant or less active growth stage. As the temperatures approached $10^{\circ} \mathrm{C}$ and higher, the canal was more susceptible to excessive algal growth. Since the temperature data was only obtained at the sampling times and not throughout the growing season, this effect requires further study.

- Water $\mathrm{pH}$ : Water $\mathrm{pH}$ may provide some insight into the development of algal problems in these systems. There were some subtle changes seen in the water chemistry data collected, but not enough data points to determine a relationship between them and the algal problems. This information is also important during the application of chemical-control agents to predict the secondary impact of a chemical-control agent. Water chemistry samples were collected during test periods, but additional information on hardness and metal content would be helpful. Copper concentrations over a the time of application would be beneficial in determining environmental fate and impacts.

- $\quad$ Light: Although not measured during this study, both the quantity and quality of light should be measured to determine its role in algal growth. The algal problems typically occur from early May to late October, when the sun reaches its maximum height over the canal. Shading was one option tested during the 1996 research period. Although shading did seem to impede algal growth, more experimentation would be necessary to determine the amount of shading necessary to eliminate algal growth. Additionally, there is little information available to assist with design requirements.

The principle constraint in obtaining this additional data is the cost of sampling. However, new instrumentation packages are becoming available that allow continuous monitoring in remote areas. These instruments allow data to be telemetered at reasonable costs. The capital costs of the instrumentation could be more than offset by providing high quality, in depth data. This type of data might allow the implementation of just-in-time algal control treatments, reducing the amount of downtime for clean-ups and the amount of chemicals purchased and released into the environment. 


\section{REFERENCES}

1. Bergy, E.A., C.A. Boettiger, and V. H. Resh, 1995, "Effects of Water Velocity on the Architecture and Epiphytes of Cladophora glomerata (Chlorophyta)," Journal of Phycology, volume 31, number 2, page 264-271.

2. Cooke, G. D., and R. H. Kennedy, 1989, "Water Quality Management for Reservoirs and Tailwaters, Report 1 - In-Reservoir Water Quality Management Techniques, U.S. Army Corps of Engineers, T.R. E-89-1, 182 pages.

3. Cooke, G. D., E. B. Welch, S. A. Peterson, and P. R. Newroth, 1989, "Restoration and Management of Lakes and Reservoirs," 2nd Edition, ISBN 0-87371-397-4, published by Lewis Publishers, Boca Raton, Florida, 548 pages.

4. Creek, Korbin, 1992, "Control of Aquatic Vegetation in PG\&E Canals," prepared by Bechtel National, Inc., San Francisco, California and PG\&E Technical and Ecological Services, San Ramon, California, 90 pages.

5. Hoagland, K. D., J. R. Rosowski, M. R. Gretz, and S. C. Roemer, 1993, "Review - Diatom Extracellular Polymeric Substances: Function, Fine Structure, Chemistry, and Physiology," Journal of Phycology, volume 29, number 5, page 537-566.

6. Ibrahim, Ezzat A., 1990, "The Influence of the Herbicide Paraquat 'Gramoxon' on Growth and Metabolic Activity of Three Chlorophytes," Water, Air, and Soil Pollution, volume 51, page 8993.

7. Janik, J. J., W. D. Taylor, and J. W. Barko, 1980, "Environmental \& Water Quality Operational Studies: A Compilation of Common Algal Control and Management Techniques," U.S. Army Engineer Waterways Experiment Station, Vicksburg, Mississippi, TRE-80-1, 77 pages.

8. Josselyn, M. and A. Fiorillo, 1993, "Control of Algal Fouling in Hydroelectric Facilities: Pilot Testing Results," (Draft Report for Pacific Gas \& Electric, Korbin Creek Manager), San Francisco State University, Tiburon, California, February, 90 pages.

9. Josselyn, M., and A. Fiorillo, 1994, "Pilot Test Results on the control of Algal Fouling in Hydroelectric Facilities," Environment, Health, and Safety Report 009.4-93.2, San Francisco State University, Tiburon, California, 111 pages.

10. Lewthwaite, J. C., A. F. Molland, and K. W. Thomas, 1985, “An Investigation into the Variation of Ship Skin Frictional Resistance with Fouling," Transactions of the Royal Institution of Naval Architects, volume 127, page 269-284.

11. McIntire, C. D., G. L. Larson, R. E. Truitt, and M.K. Debacon, 1996, "Taxonomic Structure and Productivity of Phytoplankton Assemblages in Crater Lake, Oregon," Lake and Reservoir Management, volume 12, number 2, page 259-280.

12. Murphy, K. J., and P. R. F. Barrett, 1993, "Chemical Control of Aquatic Weeds: In, Aquatic Weeds The Ecology and Management of Nuisance Aquatic Vegetation," edited by A. H. Pieterse and K. J. Murphy, published by Oxford University Press, Oxford, Great Britain, page 136-173. 
13. Patrick, R., and C. W. Reimer, 1966, "The Diatoms of the United States, Exclusive of Alaska and Hawaii. I. Fragilariaceae, Eunotiaceae, Achnanthaceae, and Naviculacea," Monographs of The Academy of Natural Sciences of Philadelphia, number 13, 688 pages.

14. Pieterse, A. H., and K. J. Murphy, 1993, "Aquatic Weeds: The Ecology and Management of Nuisance Aquatic Vegetation," ISBN 0-19-854840-0 (pbk), published by Oxford University Press, Oxford, Great Britain, 593 pages.

15. Prescott, G. W., 1982, “Algae of the Western Great Lakes Area; Revised Edition,” 6th Printing, ISBN 3-87429-205-3, published by Otto Koeltz Science Publishers, Federal Republic of Germany, 977 pages.

16. Townsin, R. L., D. Byrne, A. Milne, and T. Svensen, 1980, "Speed, Power, and Roughness: The Economics of Outer Bottom Maintenance," Transactions of the Royal Institutions of Naval Architects, volume 122, page 459-483.

17. Welch, I. M., P. R. F. Barrett, M. T. Gibson, and I. Ridge, 1990, "Barley Straw as an Inhibitor of Algal Growth. I. Studies in the Chesterfield Canal," Journal of Applied Phycology, volume 2, page 231-239.

18. Walker, W. W., Jr., and K. E. Havens, 1995, "Relating Algal Bloom Frequencies to Phosphorus Concentrations in Lake Okeechobee," Lake and Reservoir Management, volume 11, number 1, page 77-83. 
Appendix A

Bibliography 


\section{Appendix A Bibliography Index}

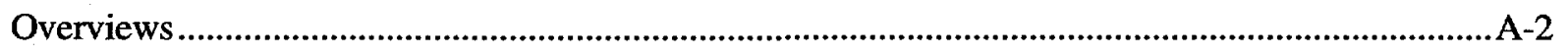

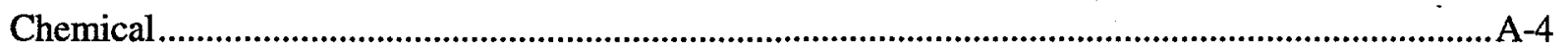

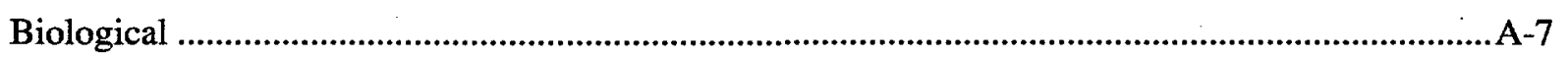

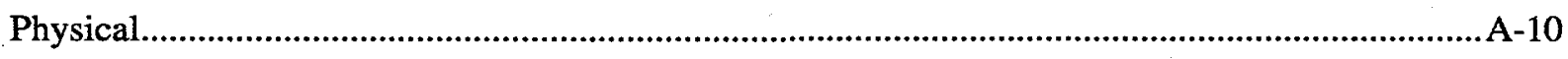

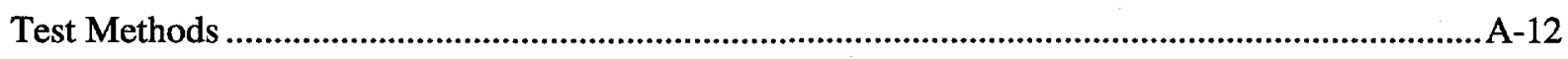

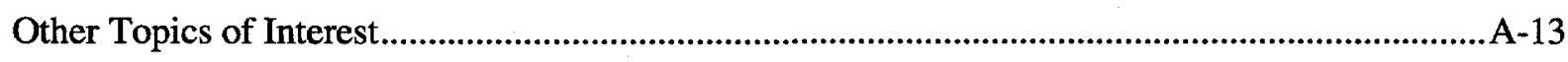


A-ii 


\section{Overviews}

Anderson, L. W. J., 1993, "Aquatic Weed Problems and Management in North America. A. Aquatic Weed Problems and Management in the Western United States and Canada: In, Aquatic Weeds The Ecology and Management of Nuisance Aquatic Vegetation," edited by A. H. Pieterse and K. J. Murphy, published by Oxford University Press, Oxford, Great Britain, page 371-391.

Charudattan. R., 1986, "Integrated Control of Waterhyacinth (Eichhornia crassipes) with a Pathogen, Insects, and Herbicides," Weed Science, volume 34, page 26-30.

Cook, C. D. K., 1993, "Origin, Autecology and Spread of Some of the World's Most Trouble-Some Aquatic Weeds: In, Aquatic Weeds The Ecology and Management of Nuisance Aquatic Vegetation," edited by A. H. Pieterse and K. J. Murphy, published by Oxford University Press, Oxford, Great Britain, page 31-38.

Fernandes, O. A., D. L. Sutton, V. H. Lallana, M. R. Sabbatini, and J. H. Irigoyen, 1993, "Aquatic Weed Problems and Management in South and Central America: In, Aquatic Weeds The Ecology and Management of Nuisance Aquatic Vegetation," edited by A. H. Pieterse and K. J. Murphy, published by Oxford University Press, Oxford, Great Britain, page 406-425.

Gangstad, E. O., and N. R. Cardarelli, 1993, "The Relation Between Aquatic Weeds and Public Health: In, Aquatic Weeds The Ecology and Management of Nuisance Aquatic Vegetation," edited by A. H. Pieterse and K. J. Murphy, published by Oxford University Press, Oxford, Great Britain, page 85-90.

Gopal, B., 1993, "Aquatic Weed Problems and Management in Asia: In, Aquatic Weeds The Ecology and Management of Nuisance Aquatic Vegetation," edited by A. H. Pieterse and K. J. Murphy, published by Oxford University Press, Oxford, Great Britain, page 318-340.

Janik, J. J., W. D. Taylor, and J. W. Barko, 1980, "Environmental \& Water Quality Operational Studies: A Compilation of Common Algal Control and Mangement Techniques,” TRE-80-1, U.S. Army Engineer Waterways Experiment Station, Vicksburg, Mississippi, 77 pages.

Joyce, J. C., 1993, "Practical Uses of Aquatic Weeds: In, Aquatic Weeds The Ecology and Management of Nuisance Aquatic Vegetation," edited by A. H. Pieterse and K. J. Murphy, published by Oxford University Press, Oxford, Great Britain, page 274-291.

Martin, B. B., D. F. Martin, and W. H. Taft, 1988, "Control of Monospecific Dinoflagellate Blooms in Florida: An Alternate View," Journal of Environmental Science and Health, volume A23, number 1, page 35-39.

Miller, A. G., D. H. Turpin, and D. T. Canvin, 1984, "Na+ Requirement for Growth, Photosynthesis, and pH Regulation in the Alkalotolerant Cyanobacterium Synechococcus leopoliensis," Journal of Bacteriology, volume 159, number 1, page 100-106.

Mitchell, D. S., A. H. Pieterse, and K. J. Murphy, 1993, "Aquatic Weed Problems and Management in Africa: In, Aquatic Weeds The Ecology and Management of Nuisance Aquatic Vegetation," edited by A. H. Pieterse and K. J. Murphy, published by Oxford University Press, Oxford, Great Britain, page 341-354. 
Mitchell, D. S., and K. H. Bowmer, 1993, "Aquatic Weed Problems and Management in AustralAsia: In, Aquatic Weeds The Ecology and Management of Nuisance Aquatic Vegetation," edited by A. H.

Pieterse and K. J. Murphy, published by Oxford University Press, Oxford, Great Britain, page 355-370.

Murphy, K. J., T. O. Robson, M. Arsenovic, and W. van der Zweerde, 1993, "Aquatic Weed Problems and Management in Europe: In, Aquatic Weeds The Ecology and Management of Nuisance Aquatic Vegetation," edited by A. H. Pieterse and K. J. Murphy, published by Oxford University Press, Oxford, Great Britain, page 295-317.

Murphy, K. J., and A. H. Piertse, 1993, "Present Status and Prospects of Integrated Control of Aquatic Weeds: In, Aquatic Weeds The Ecology and Management of Nuisance Aquatic Vegetation," edited by A. H. Pieterse and K. J. Murphy, published by Oxford University Press, Oxford, Great Britain, page 222-227.

Murphy, K. J., 1993, "Survey and Monitoring of Aquatic Weed Problems and Control Operations: In, Aquatic Weeds The Ecology and Management of Nuisance Aquatic Vegetation," edited by A. H.

Pieterse and K. J. Murphy, published by Oxford University Press, Oxford, Great Britain, page 228-237.

Pieterse, A. H., and K. J. Murphy, 1993, "Aquatic Weeds: The Ecology and Management of Nuisance Aquatic Vegetation," ISBN 0-19-854840-0 (pbk), published by Oxford University Press, Oxford, Great Britain, 593 pages.

Pieterse, A. H., 1993, "Introduction: In, Aquatic Weeds The Ecology and Management of Nuisance Aquatic Vegetation," edited by A. H. Pieterse and K. J. Murphy, published by Oxford University Press, Oxford, Great Britain, page 3-16.

Pontius, Frederick W., 1992, "A Current Look at the Federal Drinking Water Regulations," Journal of American Water Works Association, volume 84, number 3, page 36-50.

Raschke, Ronald L., 1970, "Algal Periodicity and Waste Reclamation in a Stabiliztion Pond Ecosystem," Journal Water Pollution Control Federation, volume 42, number 4, page 518-530.

Spencer, W., and G. Bowes, 1993, "Ecophysiology of the World's Most Troublesome Aquatic Weeds: In, Aquatic Weeds The Ecology and Management of Nuisance Aquatic Vegetation," edited by A. H.

Pieterse and K. J. Murphy, published by Oxford University Press, Oxford, Great Britain, page 39-73.

Sprecher, S. L., A. B. Stewart, and J.M. Brazil, 1993, "Peroxidase Changes as Indicators of HerbicideInduced Stress in Aquatic Plants," Journal of Aquatic Plant Management, volume 31, page 45-50.

Steward, K. K., 1993, "Aquatic Weed Problems and Management in North America. B. Aquatic Weed problems and Management in the Eastern United States: In, Aquatic Weeds The Ecology and Management of Nuisance Aquatic Vegetation," edited by A. H. Pieterse and K. J. Murphy, published by Oxford University Press, Oxford, Great Britain, page 391-405.

Van Vuuren, L. R. J. and F. A. Van Duuren, 1965, "Removal of Algae from Waste-Water Maturation Pond Effluent," Journal Water Pollution Control Federation, volume 37, number 9, page 1256-1262. 


\section{Chemical}

Andresen, N. A., and L. Sicko-Goad, 1993, "Effects of Trichlorobenzene on Natural Phytoplankton Populations," Ecotoxicology, volume 2, page 257-270.

Ayoub, G. M. and B. Koopman, 1986, "Algal Separation by the Lime-Seawater Process," Journal Water Pollution Control Federation, volume 58, number 9, page 924-931.

Blanck, Hans, 1985, "Inhibition of Growth of Freshwater Microalgae by Long-chained Aliphatic Amines Employed in Solvent Extraction Processes," Archives of Environmental Contamination and Toxicology, volume 14, pages 609-620.

Blatchley, E. R., III, 1993, "Disinfection and Antimicrobial Processes," Water Environment Research, volume 65 , number 4 , page 353-360.

Blenkinsopp, S. A., A. E. Khoury, and J. W. Costerton, 1992, "Electrical Enhancement of Biocide Efficiency Against Pseudomonas aeruginosa Biofilms," Applied and Environmental Microbiology, volume 58, number 11 , page $3770-3773$.

Chawner, J. A., and P. Gilbert, 1989, "Interaction of the Bisbiguanides Chlorhexidine and Alexidine with Phospholipid Vesicles: Evidence for Separate Modes of Action," Journal of Applied Bacteriology, volume 66 , page $253-258$.

Chow, Winston, 1988, "Targeted Chlorination Controls Condenser Biofouling," EPRI Journal, April/May, page 45-49.

Clark, E. A., R. M. Sterritt, and J. N. Lester, 1988, "The Fate of Tributyltin in the Aquatic Environment," Environmental Science and Technology, volume 22, number 6, page 600-604.

Collier, P. J., A. Ramsey, R. D. Waigh, K. T. Douglas, P. Austin, and P. Gilbert, 1990, "Growth Inhibitory and Biocidal Activity of Some Isothiazolone Biocides," Journal of Applied Bacteriology, volume 69, number 4, page 569-577.

Collier, P. J., A. Ramsey, R. D. Waigh, K. T. Douglas, P. Austin, and P. Gilbert, 1990, "Chemical Reactivity of Some Isothiazolone Biocides," Journal of Applied Bacteriology, volume 69, number 4, page 578-584.

Cuero, R. G., and E. B. Lillehoj, 1990, "N-Carbosymethylchitosan: Algistatic and Algicidal Properties," Biotechnology Techniques, volume 4, number 4, page 275-280.

De Vincente, A., M. Aviles, J. C. Codina, J. J. Borrego, and P. Romero, 1990, "Resistance to Antibiotics and Heavy Metals of Pseudomonas aeruginosa Isolated from Natural Waters," Journal of Applied Bacteriology, volume 68, number 6, page 625-632.

Florence, T. M. and J. L. Stauber, 1986, "Toxicity of Copper Complexes to the Marine Diatom Nitzschia closterium," Aquatic Toxicology, volume 8, page 11-26. 
Garvey, J. E., H. A. Owen, and R. W. Winner, 1991, "Toxicity of Copper to the Green Alga, Chlamydomonas reinhardtii (Chlorophyceae), As Affected by Humic Substances of Terrestrial and Freshwater Origin," Aquatic Toxicology, volume 19, page 89-96.

Gerba, C. P., K. Hou, and M. D. Sobsey, 1988, "Microbial Removal and Inactivation from Water by Filters Containing Magnesium Peroxide," Journal of Environmental Science and Health, volume A23, number 1, page 41-58.

Gilbert, P., D. Pemberton, and D. E. Wilkinson, 1990, "Synergism within Polyhexamethylene Biguanide Biocide Formulation," Journal of Applied Bacteriology, volume 69, number 4, page 593-598.

Gowrinathan, K. P., and V. N. R. Rao, 1990, "Detoxification of Copper by Nitzschia obtusa Wm. Sm., a Pennate Diatom," Bulletin of Environmental Contamination and Toxicology, volume 45, page 612-618.

Gupta, S. L., 1989, "Interactive Effects of Nitrogen and Copper on Growth of Cyanobacterium Microcystis," Bulletin of Environmental Contamination and Toxicology, volume 42, page 270-275.

Hawkins, P. R., and D. J. Griffiths, 1987, "Copper As An Algicide in a Tropical Reservoir," Water Research, volume 21, number 4, page 475-480.

Ibrahim, Ezzat A., 1990, "The Influence of the Herbicide Paraquat 'Gramoxon' on Growth and Metabolic Activity of Three Chlorophytes," Water, Air, and Soil Pollution, volume 51, page 89-93.

Jurgensen, T. A., and K. D. Hoagland, 1990, "Effects of Short-Term Pulses of Atrazine on Attached Algal Communities in a Small Stream," Archives of Environmental Contamination and Toxicology, volume 19, number 4, page 617-623.

Langeland, K. A., A. M. Fox, F. B. Laroche, B. B. Martin, D. F. Martin, C. D. Norris, and C. Wang, 1994, "Diquat Distribution in Water After Application to Submersed Weeds," Water Resources Bulletin, volume 30, number 1, page 93-97.

Lasheen, M. R., S. A. Shehata, and G. H. Ali, 1990, "Effect of Cadmium, Copper and Chromium (VI) on the Growth of Nile Water Algae," Water, Air, and Soil Pollution, volume 50, number 1/2, page 19-30.

Laube, V. M., C. N. McKenzie, and D. J. Kushner, 1980, "Strategies of Response to Copper, Cadmium, and Lead by Blue-Green and A Green Algae," Canadian Journal of Microbiology, volume 26, number 11 , page $1300-1311$.

Leland, H. V., S. N. Luoma, and J. M. Fielden, 1979, "Bioaccumulation and Toxicity of Heavy Metals and Related Trace Elements," Journal Water Pollution Control Federation, volume 51, number 6, page 1592-1611.

Les, A., and R. W. Walker, 1984, "Toxicity and Binding of Copper, Zinc, and Cadmium by the BlueGreen Alga, Chroococcus paris," Water, Air, and Soil Pollution, volume 23, page 129-139.

Libert, Carleen, 1984, "Antimicrobial Activity of Heavy Metal Salts," In: CRC Handbook of Microbiology, 2nd Edition, volume 6, Growth and Metabolism, edited by A. I. Laskin and H. A. Lechevalier, page 349-354. 
Maas-Diepeveen, J. L., and C. J. van Leeuwen, 1988, "Toxicity of Methylenebisthiocyanate (MBT) to Several Freshwater Organisms," Bulletin of Environmental Contamination and Toxicology, volume 40, page 517-524.

Murphy, K. J., and P. R. F. Barrett, 1993, "Chemical Control of Aquatic Weeds: In, Aquatic Weeds The Ecology and Management of Nuisance Aquatic Vegetation," edited by A. H. Pieterse and K. J. Murphy, published by Oxford University Press, Oxford, Great Britain, page 136-173.

Nilson E. L. and R. F. Unz, 1977, "Antialgal Substances for Iodine-Disinfected Swimming Pools," Applied and Environmental Microbiology, volume 34, number 6, page 815-822.

Oliver, R. L., R. H. Thomas, C. S. Reynolds, and A. E. Walsby, 1985, "The Sedimentation of Buoyant Microcystis Colonies Caused by Precipitation with an Iron-Containing Colloid," Proceedings Royal Society of London, series B, volume 223, page 511-528.

Pratap, K., and A.T. Lemley, 1994, "Electrochemical Peroxide Treatment of Aqueous Herbicide Solutions," Journal of Agricultural and Food Chemistry, volume 42, page 209-215.

Prows, B. L., and W. F. McIlhenny, T. E. Maloney, 1973, "Development of a Selective Algaecide to Control Nuisance Algal Growth," U.S. Environmental Protection Agency, Washington, D.C., EPA 660/3-73-006, NTIS PB-225 027/2, 126 pages.

Prows, B. L., and W. F. McIlhenny, 1974, "Research and Development of a Selective Algaecide to Control Nuisance Algal Growth," U.S. Environmental Protection Agency, Washington, D.C., EPA 660/3-74-019, NTIS PB-238 487, 220 pages.

Reddy, K. R., M. Agami, E. M. D'Angelo, and J. C. Tucker, 1991, "Influence of Potassium Supply on Growth and Nutrient Storage by Water Hyacinth," Bioresource Technology, volume 37, page 79-84.

Rijstenbil, J. W., and J. A. Wijnholds, 1991, "Copper Toxicity and Adaptation in the Marine Diatom Ditylum brightwellii," Comparative Biochemistry and Physiology, volume 100C, number 1/2, page 147150.

Rinzema, A., M. Boone, K. van Knippenberg, and G. Lettinga, 1994, "Bactericidal Effect of Long Chain Fatty Acids in Anaerobic Digestion," Water Environment Research, volume 66, number 1, page 40-49.

Rossmoore, H. W., and L. A. Rossmoore, 1991, "Effect of Microbial Growth Products on Biocide Activity in Metalworking Fluids," International Biodeterioration, volume 27, page 145-156.

Sanders, James G., 1984, "Longevity of Algal Inhibition After Chlorination of Estuarine Water," Environmental Science and Technology, volume 18, number 5, page 383-385.

Segers, L. and W. Verstraete, 1985, "Chemical Control of Eucaryotic and Blue-Green Algae in Anaerobic Photoreactors Culturing Rhodospirillaceae," Experientia, volume 41, page 99-101.

Shanmukhappa, H., and K. Neelakantan, 1990, "Influence of Humic Acid on the Toxicity of Copper, Cadmium, and Lead to the Unicellular Alga, Synechosystis Aquatilis," Bulletin of Environmental Contamination and Toxicology, volume 44, page 840-843. 
Skowronski, T., B. Pawlik, and M. Jakubowski, 1988, "Reduction of Cadmium Toxicity to Green Microalga Stichococcus bacillaris by Manganese," Bulletin of Environmental Contamination and Toxicology, volume 41, page 915-920.

Sprecher, S. L., A. B. Stewart, and J.M. Brazil, 1994, "Herbicide-Induced Stress in Aquatic Plants," Proceedings, 27th Annual Meeting, APCRP, page 156-161.

Tadros, M. G., P. Mbuthia, and W. Smith, 1990, "Differential Response of Marine Diatoms to Trace Metals," Bulletin of Environmental Contamination and Toxicology, volume 44, number 6, page 826831.

Visviki, I., and J. W. Rachlin, 1994, "Acute and Chronic Exposure of Dunaliella salina and Chlamydomonas bullosa to Copper and Cadmium: Effects on Growth," Archives of Environmental Contamination and Toxicology, volume 26, page 149-153.

Visviki, I., and J. W. Rachlin, 1994, "Acute and Chronic Exposure of Dunaliella salina and Chlamydomonas bullosa to Copper and Cadmium: Effects on Ultrastructure," Archives of Environmental Contamination and Toxicology, volume 26, page 154-162.

Winner, R. W., and H. A. Owen, 1991, "Seasonal Variability in the Sensitivity of Freshwater Phytoplankton Communities to Chronic Copper Stress," Aquatic Toxicology, volume 19, page 73-88.

\section{Biological}

Al-Shahwani, M. F. and S. F. Jazrawi, 1985, "Bioflocculation of the Effluents from Some Agricultural and Foodstuff Industries," Agricultural Wastes, volume 14, page 161-171.

Ayoub, G. M., S. I. Lee, and B. Koopman, 1986, "Seawater Induced Algal Flocculation," Water Research, volume 20, number 10, page 1265-1271.

Bernhardt, H., O. Hoyer, and B. Lusse, 1985, "Investigation on the Influence of Algogenic Organic Matter, on Flocculation and Flocseparation," Z. Wasser-Abwasser-Forsch., volume 18, page 6-17.

Best, E. P. H., 1993, "Models on Metabolism of Aquatic Weeds and Their Application Potential: In, Aquatic Weeds The Ecology and Management of Nuisance Aquatic Vegetation," edited by A. H.

Pieterse and K. J. Murphy, published by Oxford University Press, Oxford, Great Britain, page 254-273.

Bratbak, G., M. Heldal, S. Norland, and T. F. Thingstad, 1990, "Viruses as Partners in Spring Bloom Microbial Trophodynamics," Applied and Environmental Microbiology, volume 56, number 5, page 1400-1405.

Calvo, M. A., F. J. Cabanes, and L. Abarca, 1986, "Antifungal Activity of Some Mediterranean Algae," Mycopathologia, volume 93, page 61-63.

Cannell, R. J. P., 1990, "Algal Biotechnology," In: Applied Biochemistry and Biotechnology, edited by J. Weetall, published by The Humana Press, Inc., page 85-105.

Cannon, R. E., M. S. Shane, and E. DeMichele, 1974, "Ecology of Blue-Green Algal Viruses," Journal of The Environmental Engineering Division, volume 100, number 6, page 1205-1211. 
Charudattan, R., 1993, "Biological Control of Aquatic Weeds. C. Biological Control of Aquatic Weeds by Means of Fungi: In, Aquatic Weeds The Ecology and Management of Nuisance Aquatic Vegetation," edited by A. H. Pieterse and K. J. Murphy, published by Oxford University Press, Oxford, Great Britain, page 186-201.

Davey, M. C. and A. E. Walsby, 1985, "The Form Resistance of Sinking Algal Chains," British Phycological Journal, volume 20, page 243-248.

DeLucca, A. J., I, W. J. Connick, Jr., D. R. Fravel, J. A. Lewis, and J. M. Bland, 1990, "The Use of Bacterial Alginates to Prepare Biocontrol Formulations," Journal of Industrial Microbiology, volume 6, page 129-134.

DeMott, W. R., and F. Moxter, 1991, "Foraging on Cyanobacteria by Copepods: Responses to Chemical Defenses and Resource Abundance," Ecology, volume 72, number 5, page 1820-1834.

Dirlam, J. P., A. M. Belton, J. Bordber, W. P. Cullen, L. H. Huang, Y. Kojima, H. Maeada, S. Nishiyama, J. R. Oscarson, A. P. Ricketts, T. Sakakibara, J. Tone, and M. Yamada, 1990, "CP-82,996, A Novel Diglycoside Polyether Antibiotic Related to Monensin and Produced by Actinomadura sp.," Journal of Industrial Microbiology, volume 6, page 135-142.

Entzeroth, M., D. J. Mead, G. M. L. Patterson, and R. E. Moore, 1985, "A Herbicidal Fatty Acid Produced by Lyngbya aestuarii," Phytochemistry, volume 24, number 12, page 2875-2876.

Fish, S. A., and G. A. Codd, 1994, "Antimicrobial and Cytotoxic Activity Produced by an Isolate of the Thermotolerant Cyanobacterium (Blue-Green Alga) Phormidium sp.," Biotechnology Techniques, volume 8 , number 5 , page 351-356.

Flessa, Heiner, 1994, "Plant-Induced Changes in the Redox Potential of the Rhizospheres of the Submerged Vascular Macrophytes Myriophyllum verticillatum L. and Ranunculus circinatus L.," Aquatic Botany, volume 47, page 119-129.

Gadd, G. M., D. J. Gray, and P. J. Newby, 1990, "Role of Melanin in Fungal Biosorption of Tributyltin Chloride," Applied Microbiology and Biotechnology, volume 34, number 1, page 116-121.

Gleason, F. K. and J. L. Paulson, 1984, "Site of Action of the Natural Algicide, Cyanobacterin, in the Blue-Green Alga, Synechococcus sp.," Archives of Microbiology, volume 138, page 273-277.

Gleason, F. K., D. E. Case, K. D. Sipprell, and T. S. Magnuson, 1986, "Effect of the Natural Algicide, Cyanobacterin, on a Herbicide Resistant Mutant of Anacystis nidulans R2," Plant Science, volume 46, page 5-10.

Granhall, Ulf, 1972, "Aphanizomenon flos-aquae: Infection by Cyanophages," Physiologia Planta, volume 26 , number 3 , page 332-337.

Harley, K. L. S., and I. W. Forno, 1993, "Biological Control of Aquatic Weeds. B. Biological Control of Aquatic Weeds by Means of Arthropods: In, Aquatic Weeds The Ecology and Management of Nuisance Aquatic Vegetation," edited by A. H. Pieterse and K. J. Murphy, published by Oxford University Press, Oxford, Great Britain, page 177-186. 
Holmes, Paul E., 1986, "Bacterial Enhancement of Vinyl Fouling by Algae," Applied and Environmental Microbiology, volume 52, number 6, page 1391-1393.

Laws, E. A., and R. S. J. Weisburd, 1994, "Algal Control by Silver Carp: Response to Comment," The Progressive Fish-Culturist, volume 56, nubmer 1, page 70-76.

Moore, R. E., C. Cheuk, and G. M. L. Patterson, 1984, "Hapalindoles: New Alkaloids from the Blue-Green Alga Hapalosiphon fontinalis," Journal of the American Chemical Society, volume 106, page 6456-6457.

Morales, J., J. de la Noue, and G. Picard, 1985, "Harvesting Marine Microalgae Species by Chitosan Flocculation," Aquacultural Engineering, volume 4, page 257-270.

Newman, J. R., and P. R. F. Barrett, 1993, "Control of Microcystis aeruginosa by Decomposing Barley Straw," Journal of Aquatic Plant Management, volume 31, page 203-206.

Newman, Raymond M., 1991, "Herbivory and Detritivory on Freshwater Macrophytes by Invertebrates: A Review," Journal of the North American Benthological Society, volume 10, number 2, page 89-114.

Pieterse, A. H., 1993, "Biological Control of Aquatic Weeds. A. Introduction to Biological Control of Aquatic Weeds: In, Aquatic Weeds The Ecology and Management of Nuisance Aquatic Vegetation," edited by A. H. Pieterse and K. J. Murphy, published by Oxford University Press, Oxford, Great Britain, page 174-177.

Power, M. E., R. J. Stout, C. E. Cushing, P. P. Harper, F. R. Hauer, W. J. Matthews, P. B. Moyle, B. Statzner, and I. R. W. de Badgen, 1988, "Biotic and Abiotic Controls in River and Stream Communities," Journal of the North American Benthological Society, volume 7, number 4, page 456479.

Rosemond, A. D., P. J. Mulholland, and J. W. Elwood, 1993, "Top-Down and Bottom-Up Control of Stream Periphyton: Effects of Nutrients and Herbivores," Ecology, volume 74, number 4, page 1264-1280.

Safferman, R. S. and M. E. Morris, 1962, "Evaluation of Natural Products for Algicidal Properties," Applied Microbiology, volume 10, number 4, page 289-292.

Safferman, R. S., T. O. Diener, P. R. Desjardins, and M. E. Morris, 1972, "Isolation and Characterization of AS-1, a Phycovirus Infecting the Blue-Green Algae, Anacystis nidulans and Synechococcus cedrorum," Ecology, volume 47, number 1, page 105-113.

Schuring, F., J. Brederoo, A. Musgrave, and H. van den Ende, 1990, "Increase in Calcium Triggers Mating Structure Activation in Chlamydomonas eugametos," FEMS Microbiology Letters, volume 71, page 237-240.

Shapiro, J., B. Forseberg, V. Lamarra, G. Lindmark, M. Lynch, E. Smeltzer, and G. Zoto, 1983, "Experiments and Experiences in Biomanipulation: Studies of Biological Ways to Reduce Algal Abundance and Eliminate Blue-Greens," Project Summary U.S. EPA, EPA-600/S3-82-096, 5 pages. 
Smith, Daniel W., 1985, "Biological Control of Excessive Phtoplankton Growth and The Enhancement of Aquacultural Production. Canadian Journal of Fisheries and Aquatic Sciences, volume 42, number 12, page 1940-1945.

Taylor, W. D., L. R. Williams, S. C. Hern, V. W. Lambou, C. L. Howard, F. A. Morris, and M. K. Morris, 1981, "Phytoplankton Water Quality Relationships in U.S. Lakes, Part VIII: Algae Associated with or Responsible for Water Quality Problems," Project Summary U.S. EPA, EPA600/S3-80-100, 3 pages.

Van Vierssen, W., 1993, "Relationships Between Survival Strategies of Aquatic Weeds and Control Measures: In, Aquatic Weeds The Ecology and Management of Nuisance Aquatic Vegetation," edited by A. H. Pieterse and K. J. Murphy, published by Oxford University Press, Oxford, Great Britain, page 238-253.

Van der Zweerde, W., 1993, "Biological Control of Aquatic Weeds. D. Biological Control of Aquatic Weeds by Means of Phytophagous Fish: In, Aquatic Weeds The Ecology and Management of Nuisance Aquatic Vegetation," edited by A. H. Pieterse and K. J. Murphy, published by Oxford University Press, Oxford, Great Britain, page 201-221.

Van Etten, J. L., D. E. Burbank, D. Kuczmarski, and R. H. Meints, 1983, "Virus Infection of Culturable Chlorella-Like Algae and Development of a Plaque Assay," Science, volume 219, number 4587, page 994-996.

Van Etten, J. L., D. E. Burbank, Y. Xia, and R. H. Meints, 1983, "Growth Cycle of a Virus, PBCV-1, That Infects Chlorella-Like Algae," Virology, volume 126, page 117-125.

Van Etten, J. L., C. H. Van Etten, J. K. Johnson, and D. E. Burbank, 1985, "A Survey for Viruses from Fresh Water That Infect a Eucaryotic Chlorella-Like Green Alga," Applied and Environmental Microbiology, volume 49, number 5, page 1326-1328.

\section{Physical}

Ager, D. D., and R. H. Haynes, 1988, "Quantitative Aspects of the Interactive Killing Effects between X-Rays and Other Mutagens in Microorganisms," Radiation Research, volume 115, page 124-140.

Anderson, N. J., B. A. Bolto, R. J. Eldridge, L. O. Kolarik, and E. A. Swinton, 1980, "Colour and Turbidity Removal with Reusable Magnetic Particles. II. Coagulation with Magnetic Polymer Composites," Water Research, volume 14, page 967-973.

Anderson, V. J., and R. M. Thompson, 1993, "Chemical and Mechanical Control of False Hellebore (Veratrum californicum) in an Alpine Community," Intermountain Research Station, Research Paper INT-469, 6 pages.

Bare, W. F. R., N. B. Jones, and E. J. Middlebrooks, 1975, "Algae Removal Using Dissolved Air Flotation," Journal Water Pollution Control Federation, volume 47, number 1, page 153-169.

Bodien, D. G. and R. L. Stenburg, 1966, "Microscreening Effectively Polishes Activated Sludge Plant Effluent," Water and Wastes Engineering, volume 3, number 9, page 74-77. 
Choi, M. Y., C. K. Culp, T. E. Weaks, and D. J. Webb, 1992, "Artificial Aeration as a Factor Influencing the Periphytic Algal Community of Beech Fork Lake," Achiv fur Hydrobiologie, volume 123, number 4, page 497-511.

DeNicola, D. M., K. D. Hoagland, and S. C. Roemer, 1992, "Influences of Canopy Cover on Spectral Irradiance and Periphyton Assemblages in a Prairie Stream," Journal of the North American Benthological Society, volume 11, number 4, page 391-404.

De Vries, P. J. R. and H. Hillebrand, 1986, "Growth Control of Tribonema minus (Wille) Hazen and Spirogyra singularis Nordstedt by Light and Temperature," Acta Botanica Neerlandica, volume 35, number 2, page 65-70.

Golueke, C. G. and W. J. Oswald, 1965, "Harvesting and Processing Sewage-Grown Planktonic Algae," Journal Water Pollution Control Federation, volume 37, number 4, page 471-498.

Golueke, C. G. and W. J. Oswald, 1970, "Surface Properties and Ion Exchange in Algae Removal," Journal Water Pollution Control Federation, volume 42, number 8, part 2, page R304-R314.

Hader, D. P., and R. C. Worrest, 1991, "Effects of Enhanced Solar Ultraviolet Radiation on Aquatic Ecosystems," Photochemistry and Photobiology, volume 53, number 5, page 717-725.

Kroon, B. M. A., T. Burger-Wiersma, P. M. Visser, and L. R. Mur, 1992, "The Effect of Dynamic Light Regimes on Chlorella. II. Minimum Quantum Requirement and Photosynthesis-Irradiance Parameters," Hydrobiologia, volume 238, page 79-88.

Levasseur, M., J.-C. Therriault, and L. Legendre, 1984, "Hierarchical Control of Phytoplankton Succession by Physical Factors," Marine Ecology - Progress Series, volume 19, page 211-222.

McGarry, M. G. and C. Tongkasame, 1971, "Water Reclamation and Algae Harvesting," Journal Water Pollution Control Federation, volume 43, number 5, page 824-835.

Meyer, A. E., R. E. Baier, and R. W. King, 1988, "Initial Fouling on Nontoxic Coatings in Fresh, Brackish, and Sea Water," The Canadian Journal of Chemical Engineering, volume 66, page 55-62.

Middlebrooks, E. J., D. B. Porcella, R. A. Gearheart, G. R. Marshall, J. H. Reynolds, and W. J. Grenney, 1974, "Techniques for Algae Removal from Wastewater Stabilization Ponds," Journal Water Pollution Control Federation, volume 46, number 12, page 2676-2695.

Middlebrooks, E. J., D. B. Porcella, R. A. Gearheart, G. R. Marshall, J. H. Reynolds, and W. J. Grenney, 1975, "Further Evaluation of Algal Removal Techniques: Authors' Response," Journal Water Pollution Control Federation, volume 47, number 9, page 2333-2334.

Peterson, Christopher G., 1986, "Effects of Discharge Reduction on Diatom Colonization Below a Large Hydroelectric Dam," Journal of the North American Benthological Society, volume 5, number 4, page 278-289.

Reynolds, C. S., S. W. Wiseman, and M. J. O. Clarke, 1984, "Growth- and Loss-Rate Responses of Phytoplankton to Intermittent Artificial Mixing and Their Potential Application to the Control of Planktonic Algal Biomass," Journal of Applied Ecology, volume 21, page 11-39. 
Sarikaya, H. Z., and A. M. Saatci, 1988, "Optimum Pond Depths for Bacterial Die-Off," Water Research, volume 22, number 8, page 1047-1054.

Toha, J., M. A. Soto, and S. Contreras, 1990, "Phototropism in Dunaliella and Its Application in a Harvesting Device," Biotechnology Techniques, volume 4, number 5, page 321-324.

Tzeng, D. D., M. H. Lee, K. R. Chung, and J. E. DeVay, 1990, "Products in Light-Mediated Reactions of Free Methionine-Riboflavin Mixtures That Are Biocidal to Microorganisms," Canadian Journal of Microbiology, volume 36, page 500-506.

Wade, P. M., 1993, "Physical Control of Aquatic Weeds: In, Aquatic Weeds The Ecology and Management of Nuisance Aquatic Vegetation," edited by A. H. Pieterse and K. J. Murphy, published by Oxford University Press, Oxford, Great Britain, page 93-135.

Witherow, J. L. and B. E. Bledsoe, 1983, "Algae Removal by the Overland Flow Process," Journal Water Pollution Control Federation, volume 55, number 10, page 1256-1262.

\section{Test Methods}

Cloete, T. E., E. da Silva, and V. S. Brozel, 1993, "Application of Sterikon Bioindicators for the Determination of Bactericide Concentrations," Water SA, volume 19, number 4, page 343-345.

Hoffman, R. W., G. Bills, and J. Rae, 1982, "An In Situ Comparison of the Effectiveness of Four Algicides," Water Resources Bulletin, volume 18, number 6, page 921-927.

Joy, C. M., and K. P. Balakrishnan, 1990, "Effect of Fluoride on Axenic Cultures of Diatoms," Water, Air, and Soil Pollution, volume 49, page 241-249.

Kida, T. and H. Shibai, 1986, "Screening for Inhibitors of the Greening of Dark-Grown Scenedesmus obliquus C-2A', and Isolation and Biological Activity of an Active Compound, No. 381," Agricultural and Biological Chemistry, volume 50, number 2, page 483-484.

Kim, C. W., B. Koopman, and G. Bitton, 1994, "INT-Dehydrogenase Activity Test for Assessing Chlorine and Hydrogen Peroxide Inhibition of Filamentous Pure Cultures and Activated Sludge," Water Research, volume 28, number 3, page 1117-1121.

Lewis, Michael A., 1990, "Are Laboratory-Derived Toxicity Data for Freshwater Algae Worth the Effort?," Environmental Toxicology and Chemistry, volume 9, page 1279-1284.

Morton, L. H. G., 1986, "A Review of Techniques Available for Testing Algicides for Use in Terrestial and Fresh-Water Environments. International Biodeterioration, volume 22, number 1, page 5-9.

Najm, I. N., N. L. Patania, J. G. Jacangelo, and S.W. Krasner, 1994, "Evaluating Surrogates for Disinfection By-Products," Journal American Water Works Association, June, page 98-106.

Salisbury, D. K., J. V. DePinto, and T. C. Young, 1984, "Impact of Algal-Available Phosphorus on Lake Erie Water Quality: Mathematical Modeling," Project Summary U.S. EPA, EPA-600/S3-84-027, 4 pages. 
Strotmann, U. J., H. Eglsaer, and U. Pagga, 1994, "Development and Evaluation of a Growth Inhibition Test with Sewage Bacteria for Assessing Bacterial Toxicity of Chemical Compounds," Chemosphere, volume 28 , number 4 , page $755-766$.

Vaishnav, D. D., and E. T. Korthals, 1990, "Comparative Toxicities of Selected Industrial Chemicals to Microorganisms and Other Aquatic Organisms," Archives of Environmental Contamination and Toxicology, volume 19 , number 4, page 624-628.

\section{Other Topics of Interest}

Burchard, R. P., D. Rittschof, and J. Bonaventura, 1990, "Adhesion and Motility of Gliding Bacteria on Substrata with Different Surface Free Energies," Applied and Environmental Microbiology, volume 56, number 8, page 2529-2534.

Friedman, A. A., D. A. Peaks, and R. L. Nichols, 1977, "Algae Separation from Oxidation Pond Effluents," Journal Water Pollution Control Federation, volume , number , page 111-119.

McCormick, P. V., and R. J. Stevenson, 1991, "Mechanisms of Benthic Algal Succession in Lotic Environments," Ecology, volume 72, number 5, page 1835-1848.

Pitlo, R. H., and F. H. Dawson, 1993, "Flow-Resistance of Aquatic Weeds: In, Aquatic Weeds The Ecology and Management of Nuisance Aquatic Vegetation," edited by A. H. Pieterse and K. J. Murphy, published by Oxford University Press, Oxford, Great Britain, page 74-84.

Poff, N.L., N.J. Voelz, J.V. Ward, and R.E. Lee, 1990, "Algal Colonization Under Four ExperimentallyControlled Current Regimes in a High Mountain Stream," Journal of the North American Benthological Society, volume 9, number 4, page 303-318.

Schell, H. and H. Bernhardt, 1986, "Estimation of the Charge Concentration as a Governing Factor to Control the Flocculant Dose, Part 1," Z. Wasser-Abwasser-Forsch., volume 19, page 51-59.

Schell, H. and H. Bernhardt, 1986, "Estimation of the Charge Concentration as a Governing Factor to Control the Flocculant Dose, Part 2," Z. Wasser-Abwasser-Forsch., volume 19, page 60-65.

Sukenik, A., B. Teltch, A. W. Wachs, G. Shelef, I. Nir, and D. Levanon, 1987, "Effect of Oxidants on Microalgal Flocculation," Water Research, volume 21, number 5, page 533-539.

Wade, P. M., 1993, "General Biology and Ecology of Aquatic Weeds: In, Aquatic Weeds The Ecology and Management of Nuisance Aquatic Vegetation," edited by A. H. Pieterse and K. J. Murphy, published by Oxford University Press, Oxford, Great Britain, page 17-30.

Wentworth, R. L., E. Ashare, D. C. Augenstein, A. C. Sharon, E. H. Wilson, and D. L. Wise, 1978, "Cost Analysis of Growing and Harvesting Aquatic Biomass," Proceedings Second Annual Fuels From Biomass Symposium, Rensselaer Polytechnic Institute, Troy, New York, June 20-22, CONF-7806107-P2, page P873-P889. 
Appendix B

Water Quality Data 


\section{Water Quality Data Index}

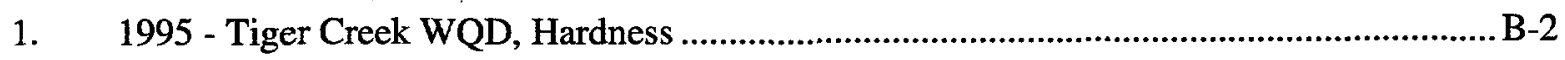

2. 1995 - Tiger Creek WQD, Conductivity ….......................................................................

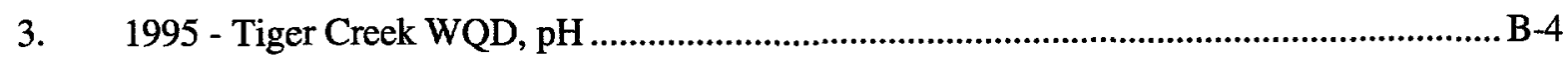

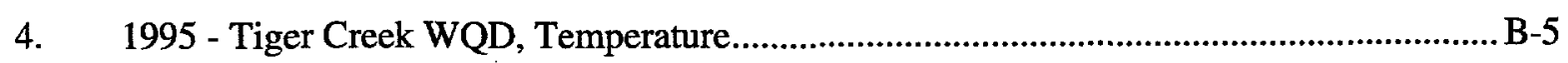

5. 1995 - Tiger Creek WQD, Copper, Flame Spectrophotometer, parts per million ................ B-6

6. 1995 - Tiger Creek WQD, Copper, Graphite Furnace, ppb ............................................... B-7

7. 1996 - Algae Control Test Program, Tiger Creek ............................................................ B-8

8. 1996 - Tiger Creek WQD, pH, Conductivity ..................................................................

9. 1996 - Tiger Creek WQD, Total Dissolved Solids, Hardness........................................... B-10

10. 1996 - Tiger Creek WQD, Copper (GFA) ......................................................................

11. 1996 - Algae Control Test Program, Drum Canal …........................................................ B-12

12. 1996 - Drum Canal WQD, pH, Conductivity, TDS, Hardness, Copper (GFA) .................. B-13 
B-ii 


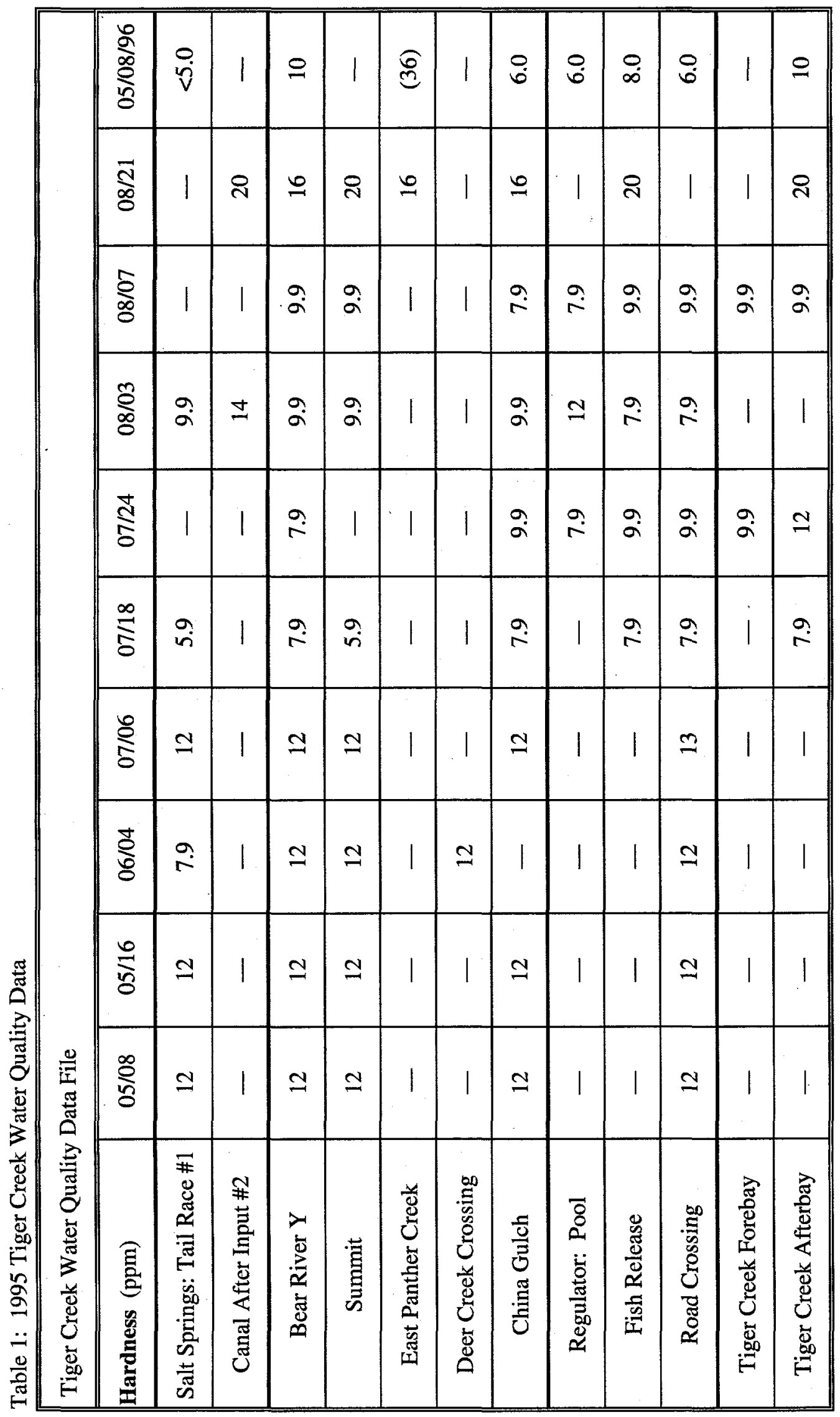




\begin{tabular}{|c|c|c|c|c|c|c|c|c|c|c|c|c|}
\hline 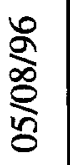 & $\stackrel{n}{8}$ & & 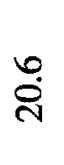 & 1 & $\widehat{\widehat{\Omega}}$ & 1 & $\underset{\sim}{\sim}$ & nे & ๗ֶ) & $\tilde{N}$ & 1 & $\begin{array}{c}\stackrel{m}{\sim} \\
\stackrel{\sim}{N}\end{array}$ \\
\hline 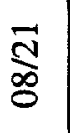 & $\begin{array}{l}8 \\
\stackrel{0}{0}\end{array}$ & & $\overrightarrow{\ddot{n}}$ & $\hat{n}$ & $\begin{array}{l}\tilde{\sigma} \\
\stackrel{n}{\sigma}\end{array}$ & 1 & $\stackrel{2}{0}$ & $\mid$ & $\begin{array}{l}\text { ? } \\
6\end{array}$ & $\begin{array}{l}\vec{a} \\
\ddot{a}\end{array}$ & 1 & $\underset{d}{-}$ \\
\hline$\stackrel{\infty}{8}$ & 1 & & $\stackrel{\vec{g}}{\sigma}$ & $\begin{array}{l}0 \\
\infty \\
-0\end{array}$ & 1 & 1 & $\begin{array}{l}0 \\
0\end{array}$ & 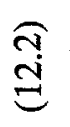 & $\stackrel{\text { }}{\stackrel{n}{g}}$ & $\begin{array}{l}\ddot{\theta} \\
\ddot{2}\end{array}$ & $\overrightarrow{ \pm}$ & 1 \\
\hline$\underset{\infty}{\infty}$ & $\mid$ & & 1 & 1 & 1 & 1 & 1 & 1 & 1 & 1 & 1 & 1 \\
\hline$\frac{\mathbb{S}}{S}$ & 1 & & $\begin{array}{l}\infty \\
\infty \\
\stackrel{\sim}{~}\end{array}$ & 1 & 1 & 1 & ָิ & $\stackrel{\vec{\infty}}{=}$ & 莳 & $\dddot{n}$ & 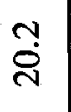 & 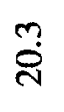 \\
\hline$\underset{\mathbf{S}}{\stackrel{\infty}{0}}$ & ¿্ं & & $\stackrel{n}{\sim}$ & $\begin{array}{l}\vec{m} \\
\stackrel{n}{n}\end{array}$ & 1 & 1 & $\stackrel{\text { ?] }}{8}$ & 1 & 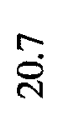 & $\begin{array}{l}f \\
\stackrel{8}{\sigma}\end{array}$ & 1 & $\stackrel{\sim}{\sim}$ \\
\hline$\stackrel{8}{5}$ & $\sigma$ & & in & $\begin{array}{l}\text { \&̊ } \\
\text { İ }\end{array}$ & 1 & 1 & $\frac{9}{6}$ & 1 & 1 & 1 & 1 & 1 \\
\hline$\underset{8}{\stackrel{8}{8}}$ & $\begin{array}{l}0 \\
\end{array}$ & & $\stackrel{9}{2}$ & $\bar{\sim}$ & 1 & ت্d & 1 & 1 & 1 & 1 & 1 & 1 \\
\hline$\stackrel{0}{\frac{0}{b}}$ & $\frac{a}{m}$ & & $\begin{array}{l}\infty \\
\text { D. }\end{array}$ & $\underset{\text { in }}{\stackrel{\circ}{\text { in }}}$ & 1 & 1 & $\begin{array}{l}0 \\
\text { gi }\end{array}$ & $\mid$ & $\mid$ & $\frac{\dot{v}}{m}$ & $\mid$ & 1 \\
\hline$\stackrel{\infty}{ֶ}$ & $\stackrel{N}{N}$ & & $\hat{\sigma}$ & $\begin{array}{l}0 \\
\text { i }\end{array}$ & 1 & 1 & i̊ & 1 & 1 & ঐ̊. & 1 & 1 \\
\hline 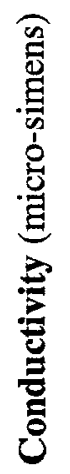 & 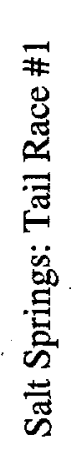 & 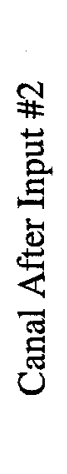 & 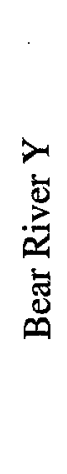 & 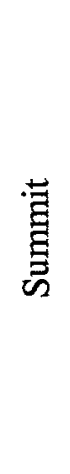 & 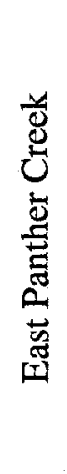 & 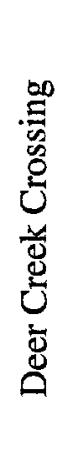 & 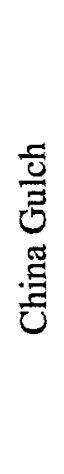 & 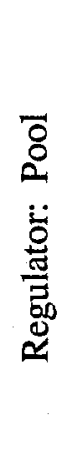 & 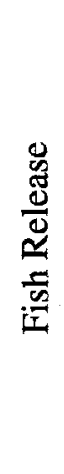 & 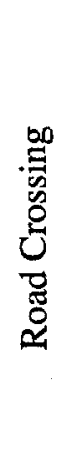 & 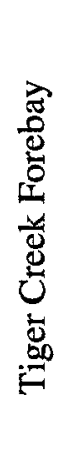 & 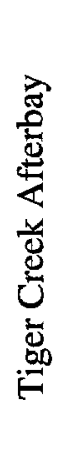 \\
\hline
\end{tabular}




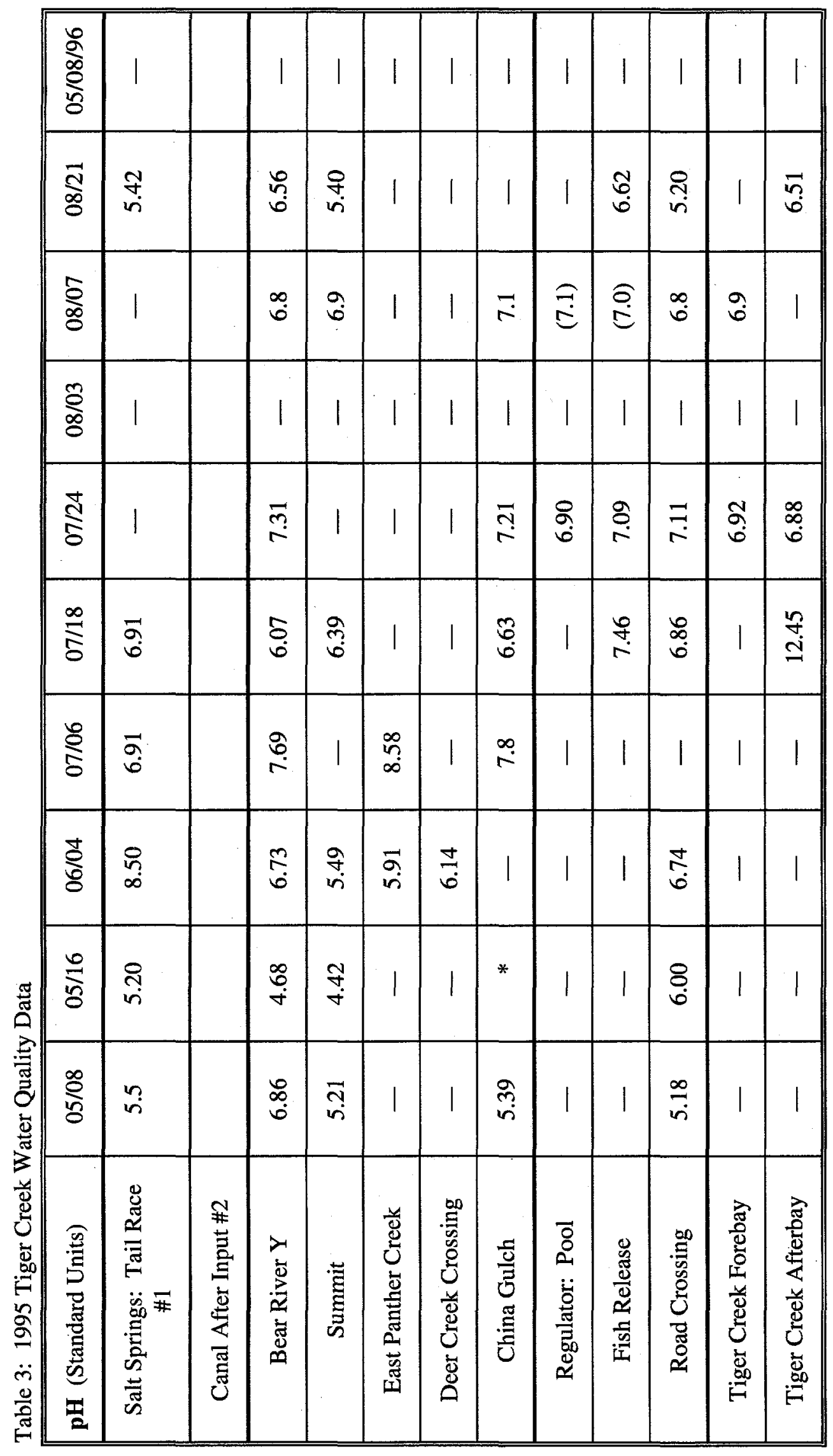

$m$ 


\begin{tabular}{|c|c|c|c|c|c|c|c|c|c|c|c|c|}
\hline 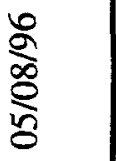 & $\stackrel{\circ}{r}$ & & r & 1 & 1 & 1 & $\mid$ & $\underset{r}{\Delta}$ & $\stackrel{\circ}{\circ}$ & $\bar{r}$ & 1 & 1 \\
\hline 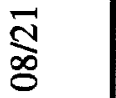 & $\ddot{\circ}$ & & $\tilde{a}$ & $\hat{a}$ & 1 & 1 & aे & 1 & O․ & $\begin{array}{l}0 \\
\sigma\end{array}$ & 1 & $\underset{\sim}{\stackrel{0}{c}}$ \\
\hline 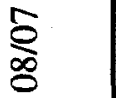 & 1 & & $\stackrel{9}{2}$ & $\infty$ & 1 & 1 & $\tilde{a}$ & & $\begin{array}{l}n \\
\tilde{n}\end{array}$ & $\tilde{\infty}$ & à & 1 \\
\hline$\overbrace{\infty}^{\infty}$ & 1 & & 1 & 1 & 1 & 1 & 1 & 1 & 1 & 1 & 1 & 1 \\
\hline 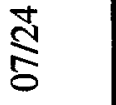 & 1 & & $\stackrel{\stackrel{N}{\Xi}}{\sim}$ & 1 & 1 & 1 & $\stackrel{m}{\check{n}}$ & $\begin{array}{l}\infty \\
\stackrel{2}{2}\end{array}$ & $\underset{\sim}{\stackrel{N}{J}}$ & $\stackrel{\nabla}{\ddot{g}}$ & $\stackrel{m}{\mathscr{O}}$ & $\stackrel{n}{=}$ \\
\hline$\stackrel{\infty}{S}^{\infty}$ & $\vec{\infty}$ & & $\mathscr{\infty}$ & $\stackrel{9}{\sim}$ & 1 & 1 & $\underset{\infty}{n}$ & 1 & $\tilde{a}$ & ナั & 1 & mo \\
\hline$\frac{\wp}{8}$ & $\stackrel{\infty}{\sim}$ & & $\begin{array}{l}\infty \\
\stackrel{0}{0}\end{array}$ & 1 & $\stackrel{\varphi}{=}$ & $\mid$ & $\overrightarrow{0}$ & 1 & 1 & 1 & 1 & $\mid$ \\
\hline$\frac{8}{8}$ & $a$ & & $\stackrel{+}{\rightleftarrows}$ & $\stackrel{\vec{g}}{\vec{g}}$ & $\begin{array}{l}0 \\
\stackrel{\sim}{\sigma}\end{array}$ & $\stackrel{\circ}{\stackrel{\oplus}{n}}$ & 1 & 1 & 1 & ą & 1 & 1 \\
\hline$\stackrel{0}{\infty}$ & $\stackrel{m}{\infty}$ & & $\tilde{\sigma}$ & $\stackrel{⿱ 亠 乂}{r}$ & 1 & 1 & $*$ & 1 & 1 & $\underset{\infty}{N}$ & 1 & 1 \\
\hline$\frac{\infty}{2}$ & $m$ & & $\ddot{\sigma}$ & $\ddot{0}$ & $\mid$ & 1 & $\stackrel{\infty}{\sim}$ & 1 & 1 & 9 & 1 & 1 \\
\hline 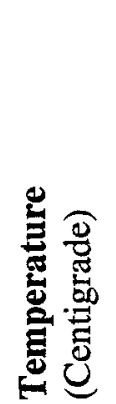 & 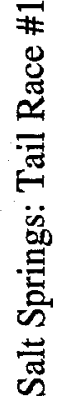 & 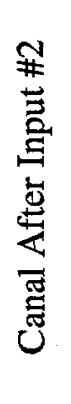 & 离 & 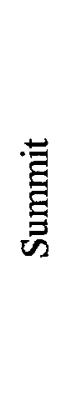 & 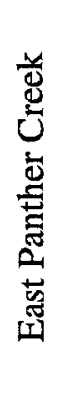 & 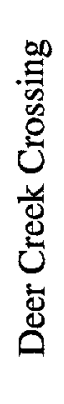 & 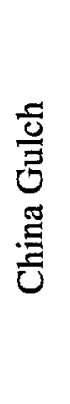 & 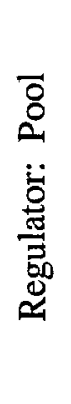 & 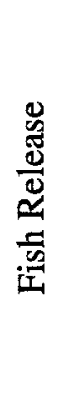 & 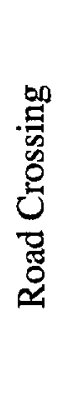 & 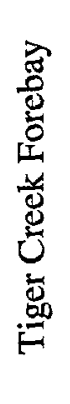 & 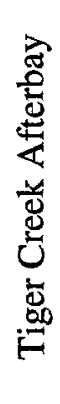 \\
\hline
\end{tabular}




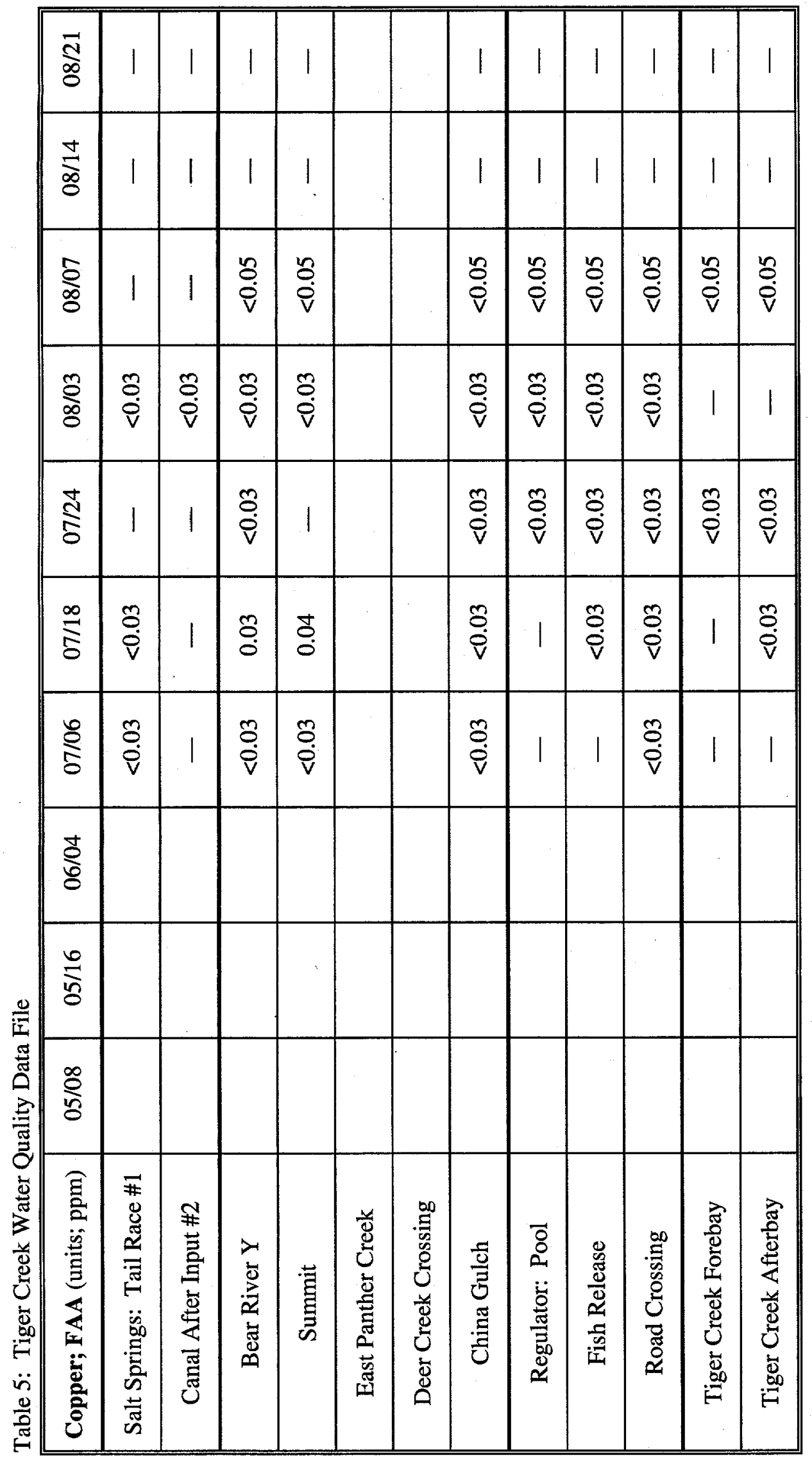




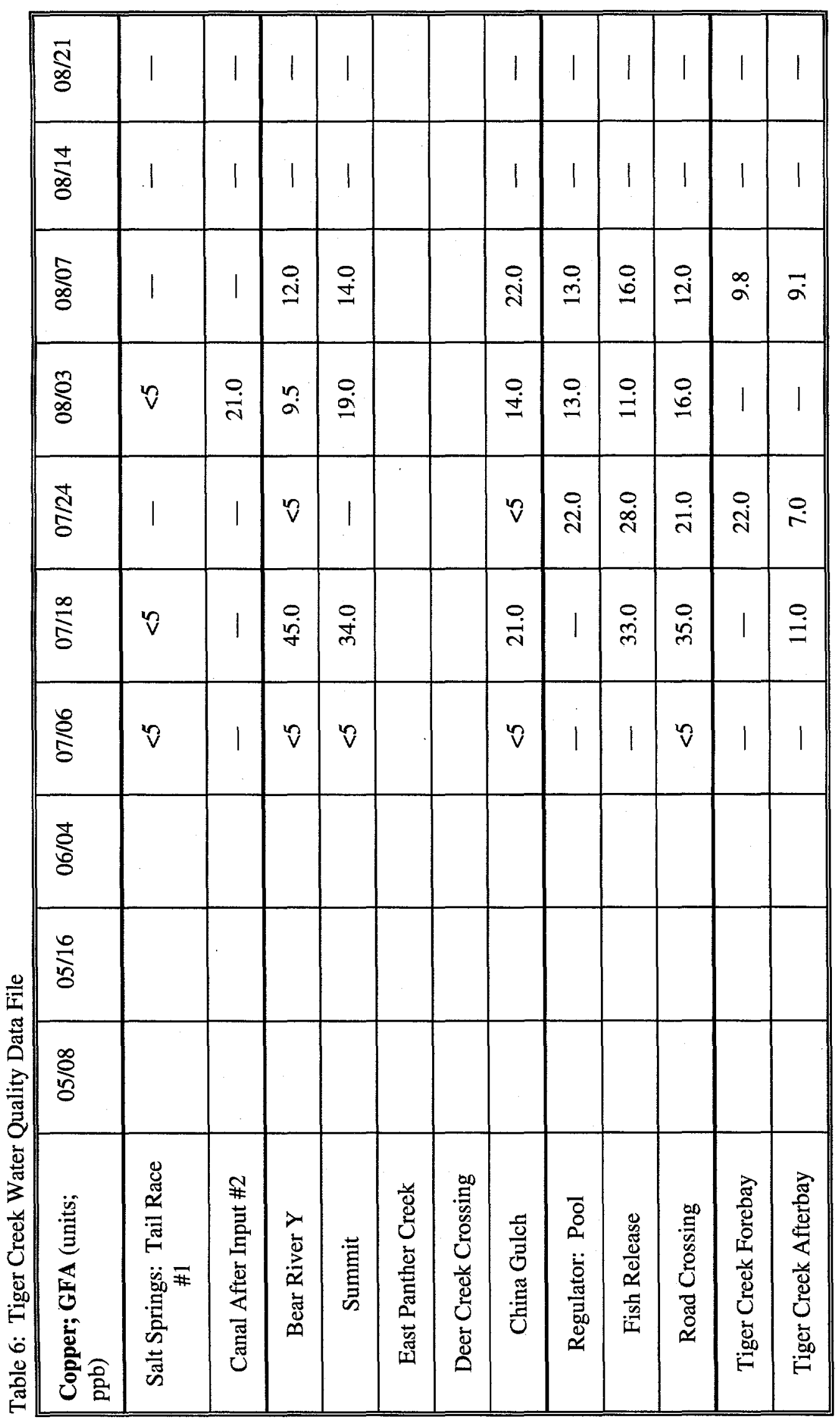


Table 7. The Water Quality Samples were collected during different tests conducted during 1996 on the Tiger Creek Canal. The testing program followed:

06/17/96 - Application \#1, 30 ppb/12 hours, EarthTec

07/03/96 - Application \#2, 30 ppb/12 hours, EarthTec

07/19/96 - Application \#3, 30 ppb/12 hours, EarthTec

07/26/96 - Application \#4, 30 ppb/12 hours, EarthTec

08/02/96 - Application \#5, 30 ppb/12 hours, EarthTec

08/09/96 - Application \#6, 30 ppb/12 hours, EarthTec

08/16/96 - Application \#7, 30 ppb/24 hours, EarthTec

08/23/96 - Application \#8, 30 ppb/12 hours, EarthTec

08/30/96 - Application \#9, 30 ppb/10.7 hours, EarthTec

09/13/96 - Application \#10, 30 ppb/12 hours, EarthTec

10/18/96 - Application \#11, 30 ppb/13.5 hours, EarthTec 


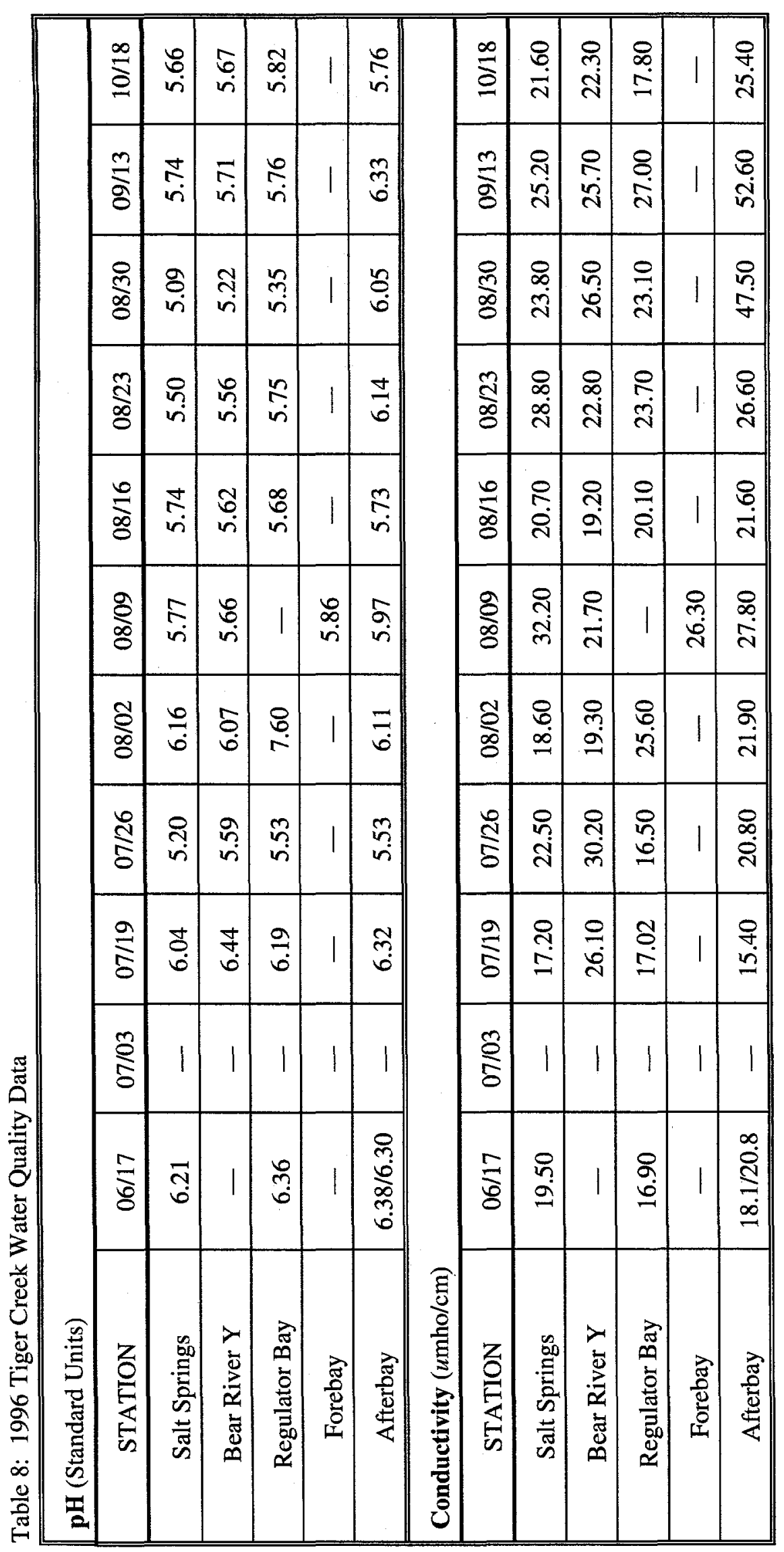




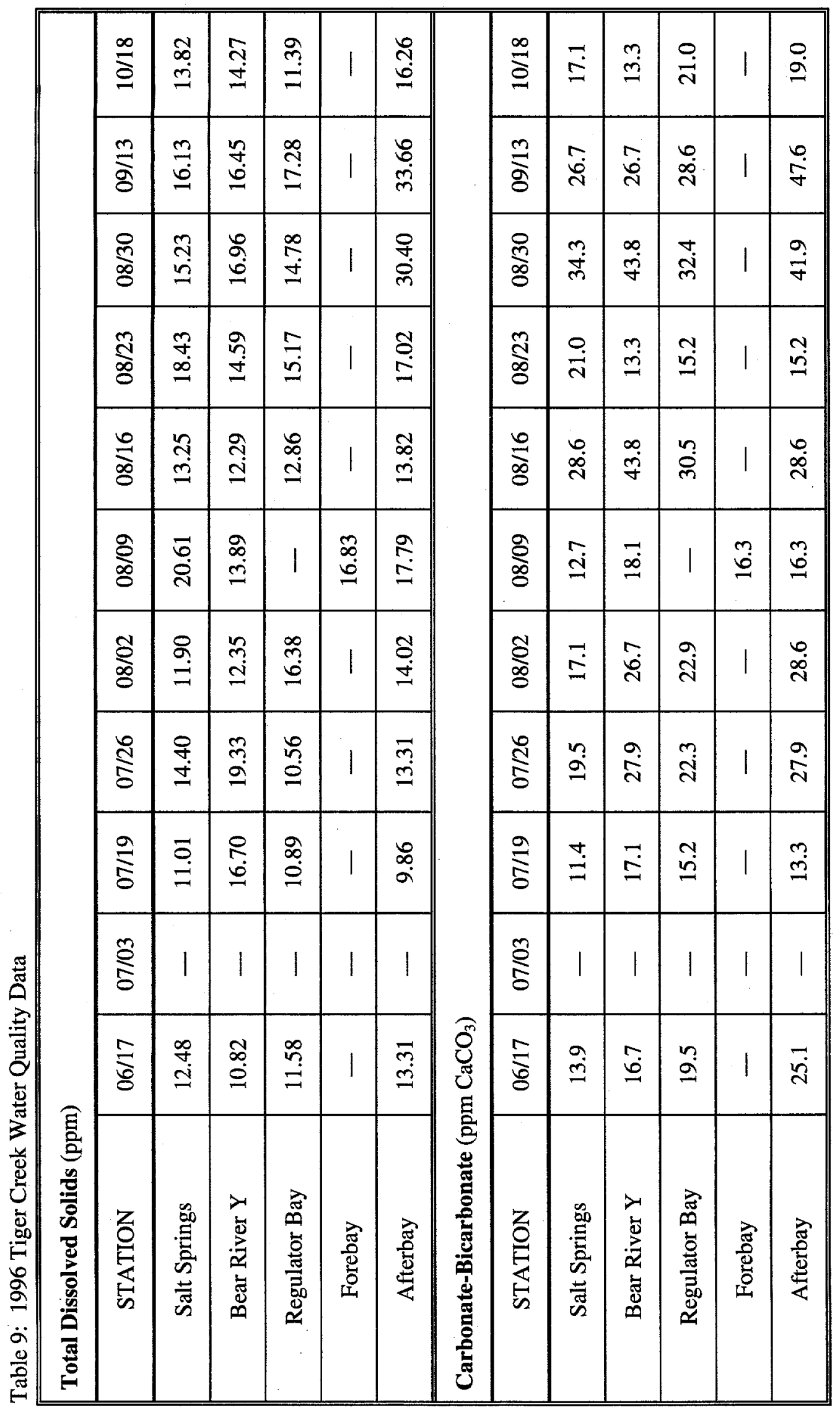

ตे 


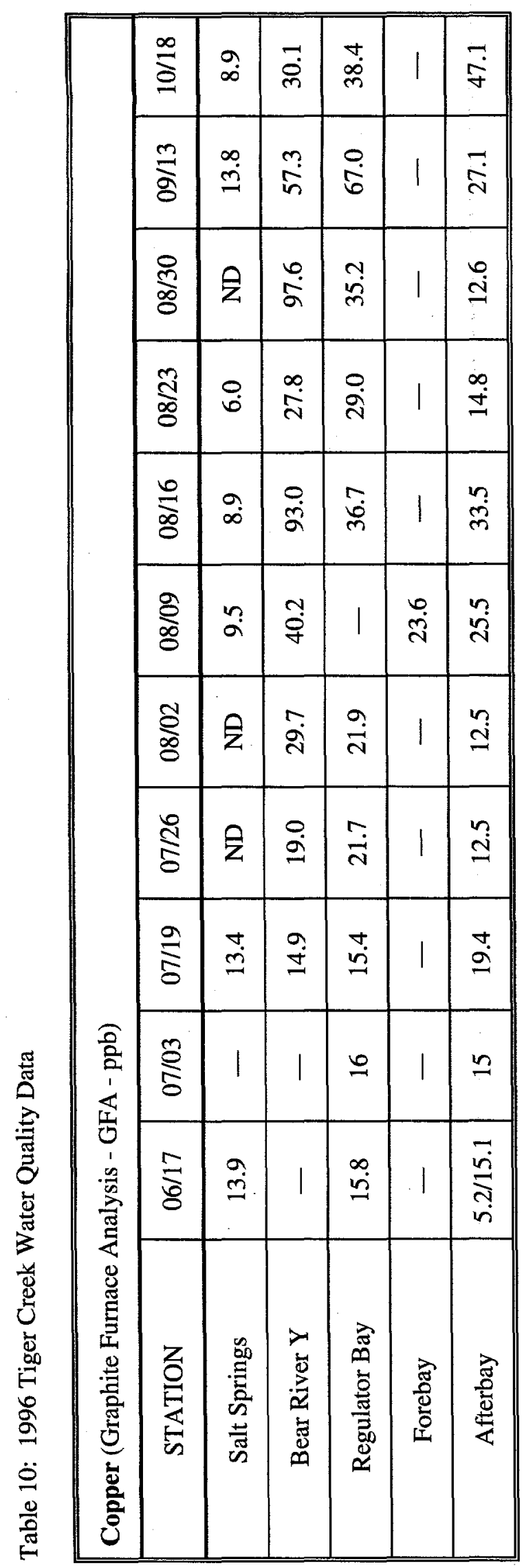


Table 11. The Water Quality Samples were collected during different tests conducted on the Drum Canal. The testing program followed:

05/07/96 - Application \#1, 22 ppb/6 hours, EarthTec

05/23/96 - Application \#2, 30 ppb/6 hours, EarthTec

06/11/96 - Application \#3, $30 \mathrm{ppb} / 12$ hours, EarthTec

07/30/96 - Application \#4, 0.5 ppm/30 minute Treatment, Strike Application

08/13/96 - Application \#5, $0.5 \mathrm{ppm} / 1$ hour Treatment, Strike Application 
Table 12: 1996 Drum Canal Water Quality Data

\begin{tabular}{|c|c|c|c|c|c|}
\hline \multicolumn{6}{|c|}{ pH (Standard Units) } \\
\hline Station & 05/07 & $05 / 23$ & $06 / 11$ & $07 / 30$ & $08 / 13$ \\
\hline YB28 & 6.31 & 6.41 & 6.07 & 6.18 & 5.89 \\
\hline HYW20 & 6.36 & 6.28 & 6.19 & - & - \\
\hline YB40 & 6.42 & 6.40 & 6.20 & 6.00 & 5.85 \\
\hline FOREBAY & 6.40 & 6.38 & 6.24 & 5.98 & 5.81 \\
\hline TAILRACE & 6.41 & 6.44 & 6.48 & - & - \\
\hline \multicolumn{6}{|c|}{ Conductivity $(u \mathrm{mho} / \mathrm{cm})$} \\
\hline Station & $05 / 07$ & $05 / 23$ & $06 / 11$ & $07 / 30$ & $08 / 13$ \\
\hline YB28 & 35.0 & 17.0 & 25.5 & 24.4 & 24.4 \\
\hline HYW20 & 47.0 & 16.1 & 22.8 & - & - \\
\hline YB40 & 24.0 & 17.1 & 23.0 & 25.2 & 26.1 \\
\hline FOREBAY & 25.0 & 18.9 & 22.7 & 24.8 & 26.2 \\
\hline TAILRACE & 43.0 & 18.9 & 23.4 & - & - \\
\hline \multicolumn{6}{|c|}{ Total Dissolved Solids (ppm) } \\
\hline Station & $05 / 07$ & $05 / 23$ & $06 / 11$ & $07 / 30$ & $08 / 13$ \\
\hline YB28 & 22.40 & 10.88 & 16.32 & 15.62 & 15.62 \\
\hline HYW20 & 30.08 & 10.30 & 14.59 & - & - \\
\hline YB40 & 15.36 & 10.94 & 14.72 & 16.13 & 16.70 \\
\hline FOREBAY & 16.00 & 12.10 & 14.53 & 15.87 & 16.77 \\
\hline TAILRACE & 24.52 & 12.10 & 14.98 & - & - \\
\hline
\end{tabular}




\begin{tabular}{|c|c|c|c|c|c|}
\hline \multicolumn{6}{|c|}{ Hardness (ppm $\mathrm{CaCO}_{3}$ ) } \\
\hline Station & $05 / 07$ & $05 / 23$ & $06 / 11$ & $07 / 30$ & $08 / 13$ \\
\hline YB28 & 8.7 & 2.9 & 11.6 & 38.1 & 21.7 \\
\hline HYW20 & 26.0 & 17.1 & 16.3 & - & - \\
\hline YB40 & 28.9 & 22.7 & 11.6 & 28.6 & 18.1 \\
\hline FOREBAY & 26.0 & 24.2 & 23.2 & 36.2 & 28.9 \\
\hline TAILRACE & 25.9 & 24.0 & 23.2 & - & - \\
\hline \multicolumn{6}{|l|}{ Copper (ppb) } \\
\hline Station & $05 / 07$ & $05 / 23$ & $06 / 11$ & $07 / 30$ & $08 / 13$ \\
\hline YB28 & ND & 15.8 & 5.6 & ND & 7.7 \\
\hline HYW20 & 5.3 & 32.4 & 14.3 & 一 & - \\
\hline YB40 & 9.9 & 79.5 & 13.5 & ND & 320.0 \\
\hline FOREBAY & 5.4 & 28.0 & 8.7 & ND & 94.5 \\
\hline TAIILACE & ND & 24.1 & 7.8 & - & - \\
\hline
\end{tabular}


B-14 
Appendix C

Decision Matrix 


\section{Appendix C}

\section{Decision Matrix}

\section{Development of Decision Matrix}

PG\&E developed the matrix formulation (Table 1, Lindquist 1995) to compare and evaluate various techniques using common criteria. By applying certain weighted values to each criteria, it is possible to rank the control technologies and determine which control technique should be considered for implementation. The categories in the Table were selected and ranked in importance based upon previous algae control experience at PG\&E.

\section{Table 1. Control Technology}

\begin{tabular}{|l|c|c|c|c|}
\hline \multicolumn{1}{|c|}{ Consideration } & Chemical & Biological & Mechanical & Combination \\
\hline Implementation Costs & $(\$ \$)$ & & & \\
\hline Operational Costs & $(\$ \$)$ & & & \\
\hline Feasibility & $*$ & & & \\
\hline Availability & $*$ & & & \\
\hline Timing & $*$ & & & \\
\hline Monitoring Needs & $*$ & & & \\
\hline Environmental Risks & $*$ & & & \\
\hline Operational Impacts & $*$ & & & \\
\hline Regulatory Risks & $*$ & & & \\
\hline Safety & $* a m e$ & & & \\
\hline Short/Long Term Solution & $*$ & & & \\
\hline R\&D Opportunity & $*$ & & & \\
\hline Champion & $*$ & & & \\
\hline
\end{tabular}

Note: ${ }^{*}$ Criteria that do not have direct costs associations are numerically weighted using $1,2,3$ to indicate high, medium, or low characteristics, Lindquist, D. 1995. 


\section{Criteria Definition}

Implementation Costs take into account the costs of installing and initiating the proposed algal control technology, and include costs related to the labor and materials required for implementation.

Operational Costs deal with the costs associated with maintaining the operational status of the control practice, after the technology is installed. While monitoring needs are addressed elsewhere, the costs associated with any monitoring requirements are also calculated under this heading.

Feasibility determines the ability to apply the technology within the existing conditions of the site. Under this consideration, it is important to identify any uncertainties and determine whether additional studies or pre-testing will be required before full implementation is possible.

Availability determines if the technology is an off-the-shelf item or requires additional development before installation. Also, it includes the identification of a commercial vendor of the practice.

Timing deals with developing a schedule for implementation of the control practice. For instance, in PG\&E's problem, algal growth does not usually begin until the first of May. The control technologies were then judged upon how much time was required to have them in place, and whether they could meet the target date.

Monitoring Needs address the collection of data to verify algae control and to support any environmental and regulatory measurements required for implementing a control strategy.

Environmental Risks are considered to be synonymous with regulatory risks; however, regulations may change over time, and materials not presently considered to be harmful may be considered hazardous as new risk factors are discovered.

Operational Impacts deal with the implementation of the algae control strategy within the framework of ongoing process activities, and address the impacts on existing operations during the implementation of the control technique.

Regulatory Risks address the sensitivity of the algae control technique within the current regulatory framework and include the manpower and other resources required to fulfill these requirements.

Safety refers to the safety of employees, personnel implementing and operating the control program, and the general public.

Short/Long Term Solution describes whether the control strategy can be used for several years or provides a temporary, stop-gap measure that can be used until a long-term solution to the algae problem can be developed.

R\&D Opportunity addresses whether it is necessary to conduct some tests to optimize the salient features of a control technology to the existing conditions for a particular algae growth problem. R\&D issues may be used to identify potential financial resources to assist in the development of a control program, since it may be possible to obtain State or Federal assistance to support the research. 
A Champion is the person who has the responsibility for assembling the basic information on the control strategy, finding answers to review committee questions, and developing the basic classification of the technique for review purposes. Without such a person, the information base on the control practice will likely be fragmented, resulting in the inability to adequately evaluate a technique.

This decision process works well when people, with different tevels professional experience and backgrounds, rate the various categories according to their knowledge and biases. It is also helpful to have consultants or vendors present descriptions of algae control techniques to the reviewers. Where appropriate, dollar amounts can be used to complete the matrix. Other categories are ranked and given a weighted value based upon the perceived level of difficulty.

After calculating a value for each category, the champions present the results. If questions are raised, the champion has the responsibility for finding answers and presenting the information at a later round of discussions. In the case of the Tiger Creek problem, several different control practices were considered for implementation this year. Three review periods were used to present information on control alternatives, answer questions about techniques, and develop the ranking. After these reviews, PG\&E had sufficient information to select the algae control strategy for implementation. 